\title{
34. MAGNETOSTRATIGRAPHY OF UPPER CENOZOIC SEDIMENTS FROM LEG 145, NORTH PACIFIC OCEAN ${ }^{1}$
}

\author{
Robin J. Weeks, ${ }^{2}$ Andrew P. Roberts, ${ }^{3}$ Kenneth L. Verosub, ${ }^{3}$ Makoto Okada, ${ }^{4}$ and Gilles J. Dubuisson ${ }^{5}$
}

\begin{abstract}
Paleomagnetic measurements were performed on whole cores and discrete samples from approximately $4 \mathrm{~km}$ of sediment recovered during Leg 145 of the Ocean Drilling Program. The obtained magnetic polarity sequences enabled the establishment of a chronostratigraphic framework from the middle Miocene (about 18.3 Ma) to the present. The quality of the magnetic record is related directly to the sedimentology: clay-rich sediments deposited since $2.6 \mathrm{Ma}$ and before $5.4 \mathrm{Ma}$ preserve a relatively strong and stable magnetic signal, whereas diatom-rich sediments deposited between 5.4 and 2.6 Ma generally contain a much weaker and less stable paleomagnetic signal. Despite these problems, Sites 884 and 887 have provided some of the longest continuous polarity sequences ever obtained in the history of ocean drilling, with continuous records obtained back to $12.6 \mathrm{Ma}$ and 18.3 Ma, respectively. Sediments at Site 881 are stably magnetized through the upper part of the thick diatom-rich interval and a continuous magnetic polarity record was obtained to the $4.03 \mathrm{Ma}(\mathrm{C} 3 \mathrm{n}$. In: Cochiti Subchron). However, extended core barrel drilling was employed below the Cochiti Subchron, at which point the paleomagnetic data substantially diminished in quality. Rotary drilling with the extended core barrel, when employed in Leg 145, seriously compromised the fidelity of the paleomagnetic record. Sites 882 and 883 provided continuous records to just below $2.6 \mathrm{Ma}$ (i.e., the Gauss/Matuyama boundary). Low remanence intensities and unstable paleomagnetic behavior prevented retrieval of a reliable magnetostratigraphy in the diatomrich interval below $2.6 \mathrm{Ma}$ at these two sites. The magnetostratigraphy from the more stably magnetized sediments of Site 884 can be transferred to the diatom-rich intervals of Sites 882 and 883 , however, by correlation of susceptibility records. This permits identification of the Gilbert/Gauss boundary and the normal subchrons within the Gilbert Chron, thus extending the records from Sites 882 and 883 to beyond $5 \mathrm{Ma}$.

The chronological constraints provided by the magnetostratigraphy are important for studying the nature of several important events that are observed throughout the North Pacific Ocean. The diatom ooze that begins near $5.4 \mathrm{Ma}$ and extends to about 2.6 Ma defines a time of extreme silica deposition in the North Pacific Ocean. This episode was observed at all Leg 145 sites and represents a short period of extreme productivity at high latitudes that is associated with an early Pliocene period of climatic amelioration. The interval beginning near the Gauss/Matuyama boundary at $2.6 \mathrm{Ma}$ is marked by high fluxes of diatoms, clay. volcanic ash, ice-rafted detritus, and quartz. The consistent appearance of abundant dropstones and other terrigenous material at the Leg 145 sites near $2.6 \mathrm{Ma}$ heralds the onset of major glaciation in the Northern Hemisphere. This suggests that the onset of glaciation in the source regions for this lithogenic material, Siberia and Kamchatka, was synchronous with the onset of Laurentide and Fennoscandian glaciation. Increased fluxes of terrigenous clays near $2.6 \mathrm{Ma}$ are also recorded at all of the Leg 145 sites and may be associated with the resurgence of bottom-current activity. An increase, by more than an order of magnitude, of volcanogenic material near 2.6 Ma in the North Pacific Ocean has also been known for many years, however, the Leg 145 sites provide much better-dated sequences for determining the timing of the onset of the northwest Pacific portion of this oceanwide volcanic episode. The long, continuous records obtained at Sites 884 and 887 permit the first direct correlation of the North Pacific Ocean diatom and other microfossil zonations to the magnetic reversal time scale in sediments older than latest Miocene.
\end{abstract}

\section{INTRODUCTION}

The North Pacific Ocean contains a critically important record of Cenozoic paleoceanographic and paleoclimatic events that were relatively poorly known prior to Leg 145 of the Ocean Drilling Program (ODP). Existing sedimentary records from the North Pacific Ocean are few and are generally disturbed by rotary drilling. The major objectives of Leg 145 were to obtain high-resolution records of Miocene to Quaternary changes in ocean circulation, biological activity, and global climate. New coring techniques used during Leg 145 allowed recovery of long, essentially undisturbed, sedimentary records

Rea, D.K., Basov, I.A., Scholl, D.W., and Allan, J.F. (Eds.), 1995. Proc. ODP, Sci. Results, 145: College Station, TX (Ocean Drilling Program).

Department of Geological Sciences, University of Washington, Seattle, WA 98115, U.S.A.

3epartment of Geology, University of California, Davis, CA 95616, U.S.A.

${ }^{4}$ Ocean Research Institute, University of Tokyo, 1-15-1 Minamidai, Nakano-ku, Tokyo 164, Japan.

'Départment de Géologic. Ecole Normale Supérieur, 75231 Paris 05, France. that totaled over $4 \mathrm{~km}$ in length: a record approached by few cruises during the history of the ODP and the Deep Sea Drilling Project. Obtaining a high-quality magnetic stratigraphy from these records is crucial to the success of developing a chronostratigraphic framework for the history of Cenozoic paleoceanographic and paleoclimatic events in the North Pacific Ocean.

Cores were drilled at seven sites during Leg 145, in a transect across the North Pacific Ocean (Fig. 1). Given the importance of obtaining a secure temporal framework for the North Pacific sedimentary sequences, we have focused on obtaining as reliable a magnetostratigraphy as possible by conducting measurements on a large number of discrete samples as a supplement to the continuous longcore measurements made during Leg 145. We present the results of these detailed studies in this paper.

\section{METHODS}

Paleomagnetic measurements were routinely carried out on the archive halves of the $1.5-\mathrm{m}$ core sections of nearly all of the sediments recovered during Leg 145 using the shipboard three-axis $2 \mathrm{G}$ 


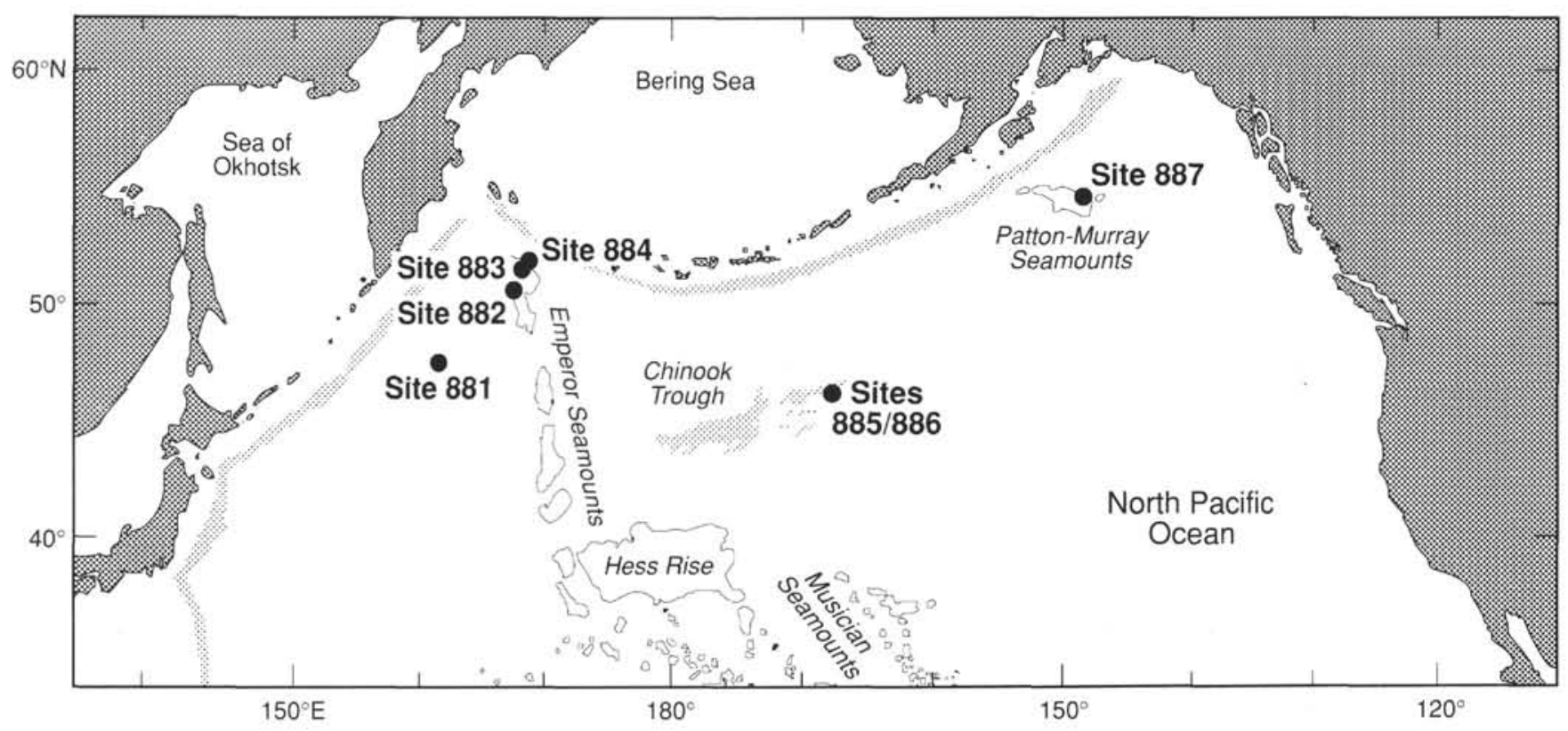

Figure 1. Map of the North Pacific Ocean showing the location of Leg 145 drill sites.

Enterprises (Model 760R) long-core pass-through cryogenic magnetometer. The high rate of core recovery and correspondingly large volume of shipboard measurements dictated a measurement strategy designed to minimize nonessential measurements. Cores were therefore demagnetized at $15 \mathrm{mT}$ and measured at $10-\mathrm{cm}$ intervals. Measurements of the natural remanent magnetization (NRM) were made on selected sections to provide information on the nature of magnetically soft (viscous) secondary overprints. The sensing coils in the cryogenic magnetometer measure signals over about a $20-\mathrm{cm}$ inter$\mathrm{val}$, and the coils for each axis have slightly different response functions. Because of the width of the sensing regions, about 200-300 $\mathrm{cm}^{3}$ of cored material contributes to the signal at the sensors. Our standard procedure was to normalize the measurements from the vertical, axial and horizontal axes of the magnetometer by the response curve for each axis (cf. Weeks et al., 1993). This produced a relatively unbiased estimate of the average direction and intensity of the sediment contained within the response region of each sensor and minimized section end effects. The large volume of core material within the sensing region permits accurate determination of the remanence of weakly magnetized samples, despite the relatively high level of background noise caused by the motion of the ship.

Single samples were taken at about $50-\mathrm{cm}$ intervals from most cores. Alternating field (AF) demagnetizations were performed on single samples on board, using both a Molspin spinner magnetometer with a Schonstedt AF demagnetizer and an automated Japanese ringcore spinner magnetometer (designed by N. Niitsuma). Results from the continuous and discrete shipboard measurements were presented in the Leg 145 Initial Reports volume (Rea, Basov, Janecek, PalmerJulson, et al., 1993). Because the magnetostratigraphy reported earlier was based largely on continuous measurements at a single demagnetization level, a further 700 discrete paleomagnetic samples from Sites 881,884 , and 887 were measured at the Paleomagnetism Laboratory at the University of California, Davis (UC-Davis), in order to provide further constraints on the magnetostratigraphy. These measurements were also made using a 2G Enterprises (Model 760R) cryogenic magnetometer in conjunction with a Schonstedt AF demagnetizer. Samples were routinely demagnetized at levels of 0,10 , $20,30,40$, and $50 \mathrm{mT}$. Application of an anhysteretic remanent magnetization (ARM) and subsequent demagnetizations of the ARM were performed on some samples on board using the Japanese spinner magnetometer. Other mineral magnetic measurements, including high-field hysteresis measurements (using a Princeton Measurements Corporation Micromag alternating gradient magnetometer) were made at UC-Davis. Detailed results of mineral magnetic studies of middle and upper Pleistocene sediments from Sites 883, 884, and 887 are presented by Roberts et al. (this volume).

One of the problems associated with drilling is that it is usually not possible to obtain a fully continuous record because of coring disturbances and gaps in coring. Depths are usually reported as depths below seafloor. However, because of these problems, reported depths do not always correspond to true depths in the hole. During Leg 145, a downhole logging tool was used to measure magnetic susceptibility. Correlation of the magnetic susceptibility between the downhole record and the core allow construction of a true depth scale for major boundaries which eliminates the uncertainty due to core gaps. This provides a more accurate means of determining sedimentation and mass-accumulation rates. The susceptibility records also allow correlations between holes and between nearby sites, so that higher quality magnetic records found at a given location can be transferred to aid interpretation of lower quality records at another site location. The long-core magnetostratigraphy obtained at Site 884 was used in this way to aid the interpretation of poorer quality records from Sites 882 and 883 .

\section{RESULTS}

The quality of the magnetostratigraphic record at each site is related directly to the sedimentology: clay-rich sediments deposited after 2.6 Ma and prior to 5.4 Ma preserve a strong and generally stable magnetic signal, whereas diatom-rich sediments deposited between 5.4 and 2.6 Ma generally contain a much weaker, and less stable, paleomagnetic signal. We therefore discuss the magnetostratigraphic interpretation for each site with respect to the three intervals from 0 to $2.6,2.6$ to 5.4 , and before $5.4 \mathrm{Ma}$. These intervals are generally coincident with lithologic Units IA, IB, and II (and below), as shown in Figure 2. Dates for all polarity boundaries are taken from the magnetic polarity time scale of Cande and Kent (1992). 

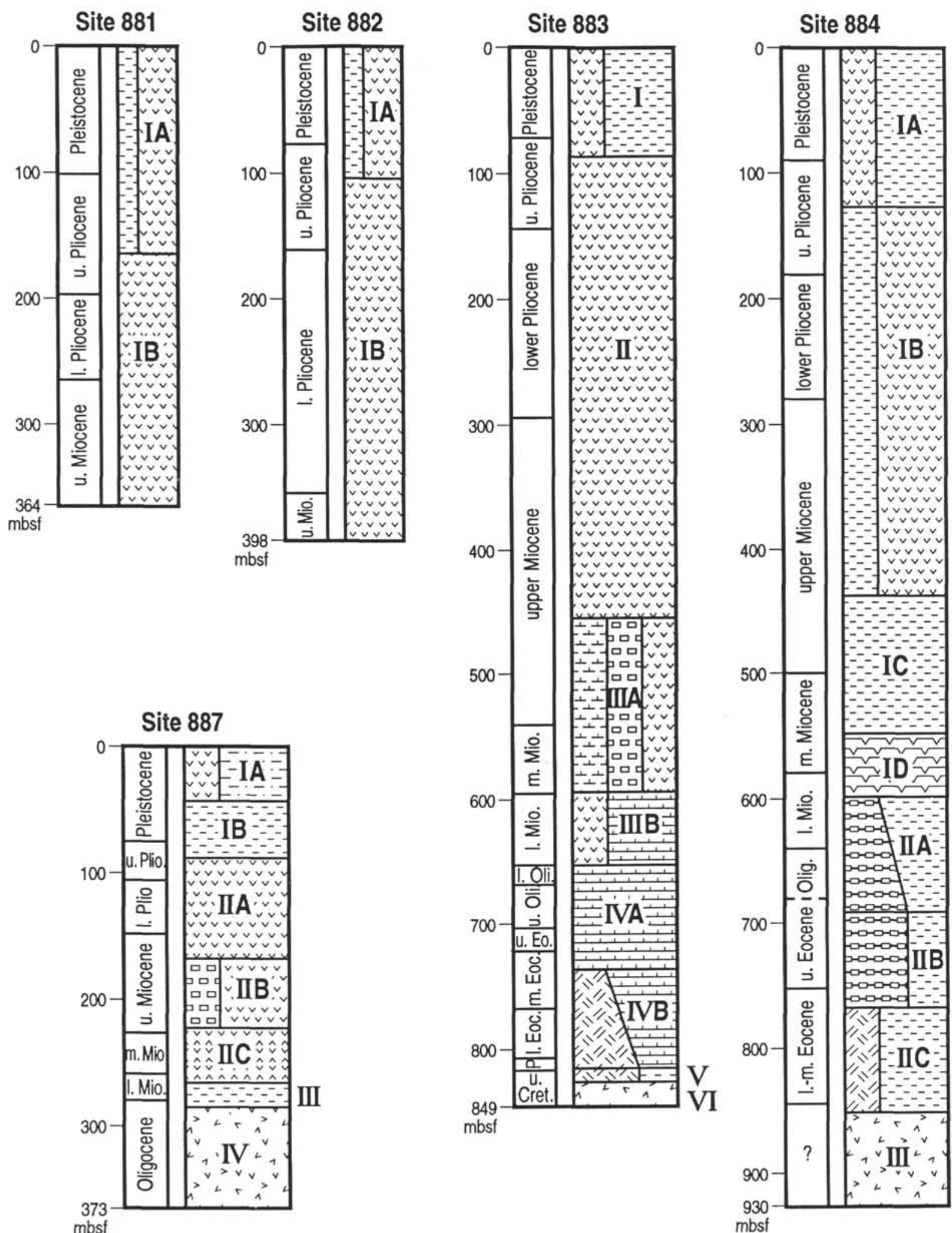

Figure 2. Lithology, lithologic subdivision, and age of sediments recovered on Leg 145. Symbols are: dashes = silt and clay; v's = siliceous ooze; rectangles and brick patterns $=$ carbonates; alternating diagonal hash marks $=$ ash; lowermost stippled pattern $=$ basalt. Roman numerals with capitalized letters indicate lithologic units and subunits. 


\section{Site $\mathbf{8 8 1}$}

Pass-through measurements of NRM intensity, demagnetized at $15 \mathrm{mT}$, and whole-core low-field magnetic susceptibility are shown in Figure 3 for Holes 881B and 881D. Results of single-sample demagnetizations, made on board and at UC-Davis, are superimposed on the pass-through measurements of inclination in Figure 4. Data from single samples were determined from least-squares line fits to the characteristic remanence component between 20 and $50 \mathrm{mT}$ (Fig. $5)$. Remanence intensities are generally high $(5-50 \mathrm{~mA} / \mathrm{m})$, with scattered high susceptibility $\left(>300 \times 10^{-6} \mathrm{SI}\right)$ values that usually coincide with occurrences of dropstones or black volcanic ash layers (Fig. 3). NRM intensities and susceptibilities decrease by almost an order of magnitude at a depth of about 160 meters below seafloor (mbsf). This transition coincides with the boundary between lithologic Subunits IA and IB (Fig. 2), where the clay content and the percentage of ash layers both decrease abruptly and the sediment becomes dominated by diatomaceous ooze.

With the exception of a few apparently disturbed regions of the cores, the sediments appear to record stable normal and reversed geomagnetic field directions (Fig. 4; the axial dipole field inclination is $\pm 65.1^{\circ}$ at a latitude of $47^{\circ} 6^{\prime} \mathrm{N}$ ). AF demagnetization of discrete samples generally isolates a characteristic component that is directed toward the origin of vector component diagrams (Fig. 5). These samples also contain a secondary overprint that is removed at fields of 5$10 \mathrm{mT}$. This overprint almost invariably has a steeply reversed direction (i.e., parallel to the core barrel). This suggests that the overprint is a low-field isothermal remanent magnetization (IRM) resulting from the drilling. Because this overprint is magnetically "soft," the whole-core measurements after demagnetization at $15 \mathrm{mT}$ were used for the magnetostratigraphic interpretation at this site. Paleomagnetic directions determined from discrete samples are consistent with this interpretation (Fig. 4) and provide strong evidence that a primary component of magnetization is reliably isolated at demagnetization levels of $15 \mathrm{mT}$.

The magnetostratigraphic interpretation for Site 881, presented in Figure 4 , was constructed with the aid of the biostratigraphic framework established for this site (Barron and Gladenkov, this volume). Identification of the Matuyama/Brunhes reversal and the Jaramillo and Olduvai subchrons is straightforward in Hole 881B. Below the Olduvai Subchron, two periods of normal polarity are identified and are assigned to the Réunion and the ' $\mathrm{X}$ '-anomaly events, although the Hole $881 \mathrm{~B}$ polarity intervals are much thicker than would be expected for these events (cf. Cande and Kent, 1992). We correlate the Gauss/Matuyama boundary with the reversal at the base of Hole $881 \mathrm{~B}$. Correlation between Holes $881 \mathrm{~B}$ and $881 \mathrm{C}$ becomes difficult at the presumed location of the Olduvai Chron, which does not appear to be recorded in Hole $881 \mathrm{C}$. This is not the result of a depth offset between the two holes because their whole-core susceptibility and gamma-ray attenuation porosity evaluator (GRAPE) records clearly correlate, indicating no more than a $1-\mathrm{m}$ offset at these depths. Thus, either an extra event is recorded in Hole $881 \mathrm{~B}$ or an event is missing in Hole $881 \mathrm{C}$ in the $100-110 \mathrm{mbsf}$ interval. Anomalously shallow reversed directions occur at depths where the Olduvai Subchron would be expected in Hole $881 \mathrm{C}(100-110 \mathrm{mbsf})$. A possible explanation for the missing subchron is the observation of apparent dips as high as $60^{\circ}$ and clear evidence for disturbance of the sediments at these depths in Hole $881 \mathrm{C}$. Untilting the anomalously shallow reversed directions in Hole $881 \mathrm{C}$ may restore directions to normal polarity in this zone.

Advanced piston cores (APC) were obtained to a depth of 155.8 mbsf in Hole $881 \mathrm{C}$, below which cores were recovered with the extended core barrel (XCB). Paleomagnetic directional data from the $\mathrm{XCB}$ cores were not sufficiently consistent to enable interpretation in terms of magnetostratigraphy at Hole $881 \mathrm{C}$. However, the APC core data from Hole 881D (155-212 mbsf) are of excellent quality (Fig. 4) and provide clear identification of the Gauss/Matuyama and Gilbert/ Gauss polarity boundaries, as well as the Kaena and Mammoth subchrons. A continuous magnetostratigraphy is therefore available for this site from the present to the top of the Cochiti Subchron at 4.03 $\mathrm{Ma}$. Depths to polarity boundaries are given in Table 1 .

\section{Site 882}

Pass-through measurements of NRM intensity, whole-core magnetic susceptibility, and paleomagnetic inclination are shown in Figures 6 and 7 for Hole 882A. Remanence intensities and susceptibilities are relatively high in the upper part of Hole 882A and decrease gradually with depth to $105 \mathrm{mbsf}$, where they abruptly diminish by about one order of magnitude. This transition again coincides with the decrease in clay content and percentage of ash layers at the boundary between lithologic Subunits IA and IB, where the sediment becomes dominated by diatomaceous ooze (Fig. 2). Sharp peaks in NRM intensity and susceptibility occur throughout the sequence and commonly coincide with the black and brown ash layers. The amplitude and frequency of these peaks diminishes markedly below 105 mbsf.

The new core barrel used at this site did not appear to carry a significant remanent magnetization because the consistent drilling overprint observed at Site 881 was not evident at Site 882 . Demagnetization of discrete samples (Fig. 8) demonstrates that secondary overprints are usually small and are consistent with a viscous origin. With the exception of disturbed parts of the cores, the sediments appear to record stable normal and reversed field directions (the axial dipole field inclination is $\pm 68.1^{\circ}$ at a latitude of $51^{\circ} 11^{\prime} \mathrm{N}$ ) in the first $105 \mathrm{~m}$ of Hole $882 \mathrm{~A}$ as well as in the top $45 \mathrm{~m}$ of Hole $882 \mathrm{~B}$. Sediments were not measured below 48 mbsf in Hole $882 \mathrm{~B}$.

Demagnetization of single samples isolates a stable magnetization that is directed toward the origin of vector component plots in the upper part of Hole 882A (Fig. 8). However, within this interval, discrete sample demagnetizations reveal unstable behavior in some restricted stratigraphic intervals, notably 40.0-44.0, 54.3-56.3, and 83.0-85.0 mbsf (Figs. 7 and 8). Repeat demagnetizations of samples from these zones at a given demagnetization step produce widely different directional results which implies that the samples are susceptible to the acquisition of random magnetic moments during the AF demagnetization process. The zones correspond to what appear to be short normal events in the measured whole-core magnetization. We believe that these events are artifacts resulting from remagnetization of these intervals during the pass-through demagnetization. For the magnetostratigraphic interpretation, the single-sample data were used to distinguish well-behaved regions of the cores from those susceptible to such remagnetizations. With the exception of the problem intervals discussed above, the data from the discrete samples are in almost exact agreement with the long-core results (Fig. 7).

Data from Hole $882 \mathrm{~B}(0-45 \mathrm{mbsf})$ agree well with those from Hole $882 \mathrm{~A}$ (Fig. 7). The Matuyama/Brunhes boundary occurs at approximately the same depth in both holes $(35.3 \mathrm{mbsf}$ in $882 \mathrm{~B}$ compared to $35.5 \mathrm{mbsf}$ in $882 \mathrm{~A}$ ). The magnetostratigraphic record of Hole $882 \mathrm{~A}$ can be readily matched to the time scale of Cande and Kent (1992) as far as the Gauss/Matuyama boundary, which occurs at approximately $98 \mathrm{mbsf}$ (Fig. 7). Magnetostratigraphic interpretation of the interval from 105 to 300 mbsf is not possible due to low intensities of magnetization which results in a noisy and inconsistent polarity signal (Fig. 9). However, from 300 mbsf to the base of Hole $882 \mathrm{~A}$ at $398.3 \mathrm{mbsf}$, within Subunit IB, clay contents increase, NRM intensities become stronger and a more coherent magnetostratigraphy again emerges (Fig. 9). The polarity sequence is dominated by reversed polarity and contains several zones of normal polarity. Such a pattern is not sufficiently diagnostic to make an unambiguous correlation of this interval with the polarity time scale. However, biostratigraphic data (Barron and Gladenkov, this volume) suggest that the 

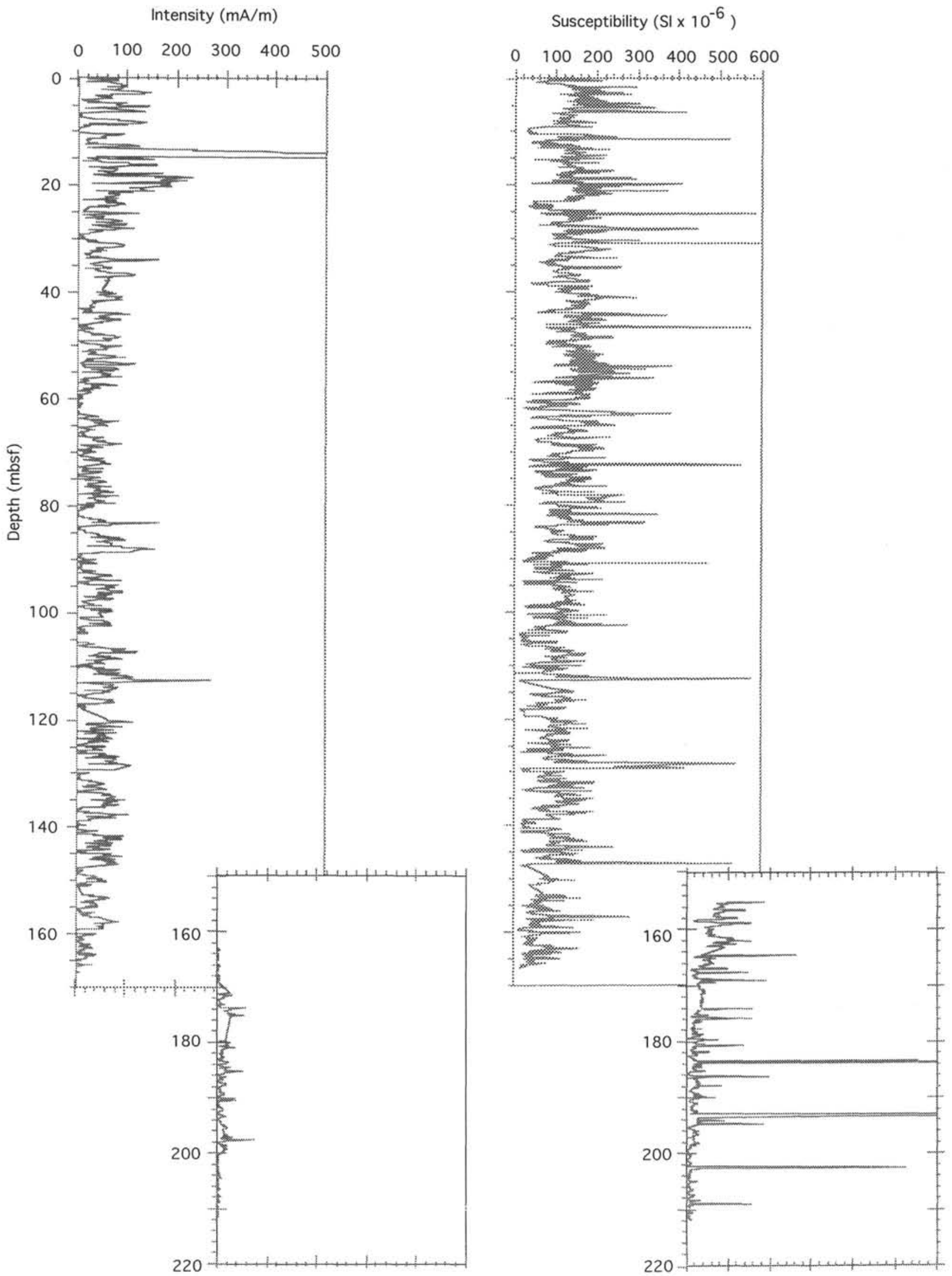

Figure 3. NRM intensities compared to the whole-core susceptibility from Hole 881B. The lower part of the record is from Hole 881D. 


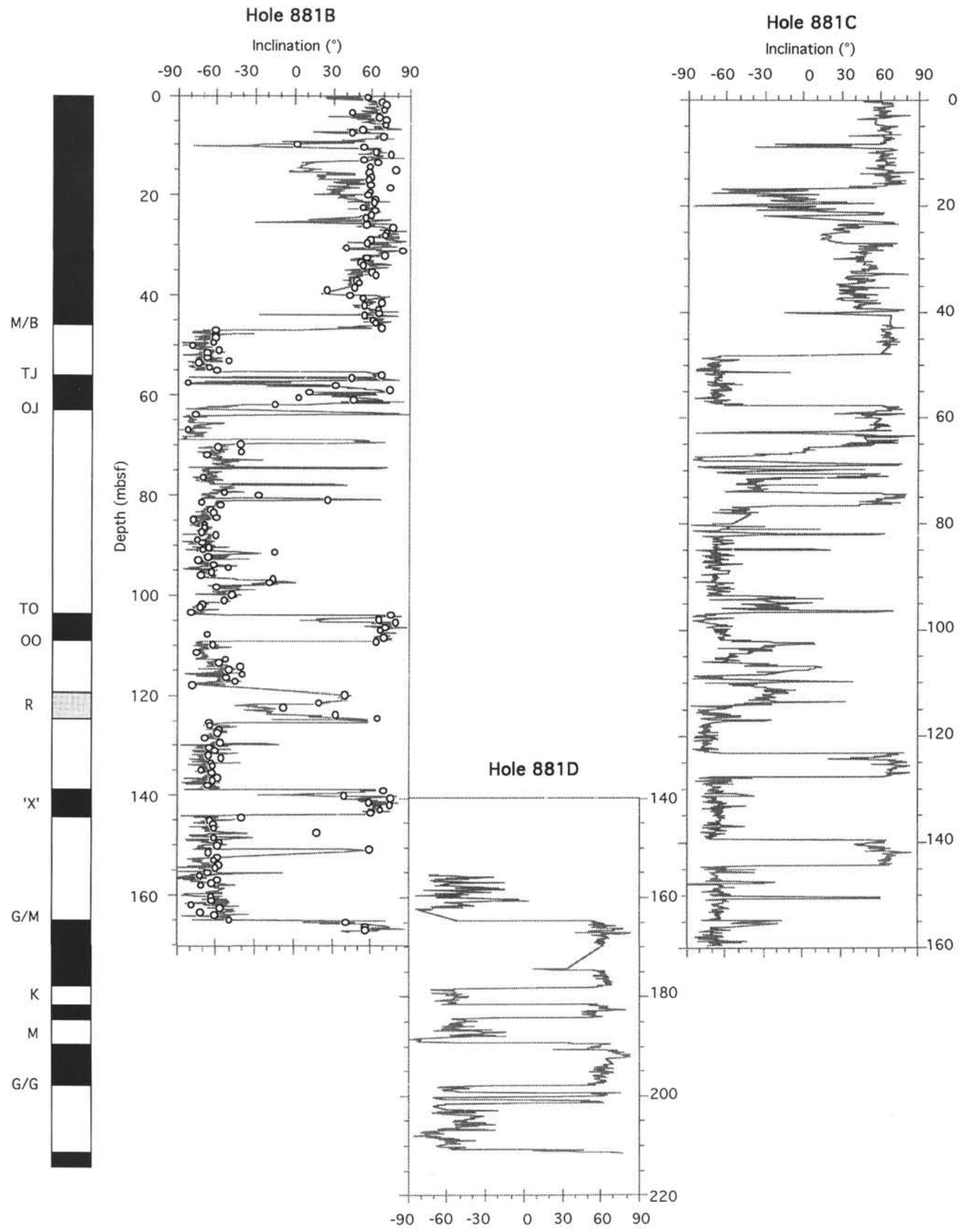

Figure 4. Paleomagnetic inclinations from Holes $881 \mathrm{~B}, 881 \mathrm{C}$, and $881 \mathrm{D}$. Paleomagnetic directions from single samples, obtained by least-squares line fits to demagnetization results between 20 and $50 \mathrm{mT}$, are superimposed as points on the long-core results from Hole $881 \mathrm{~B}$. The magnetostratigraphic interpretation is shown on the polarity log. 


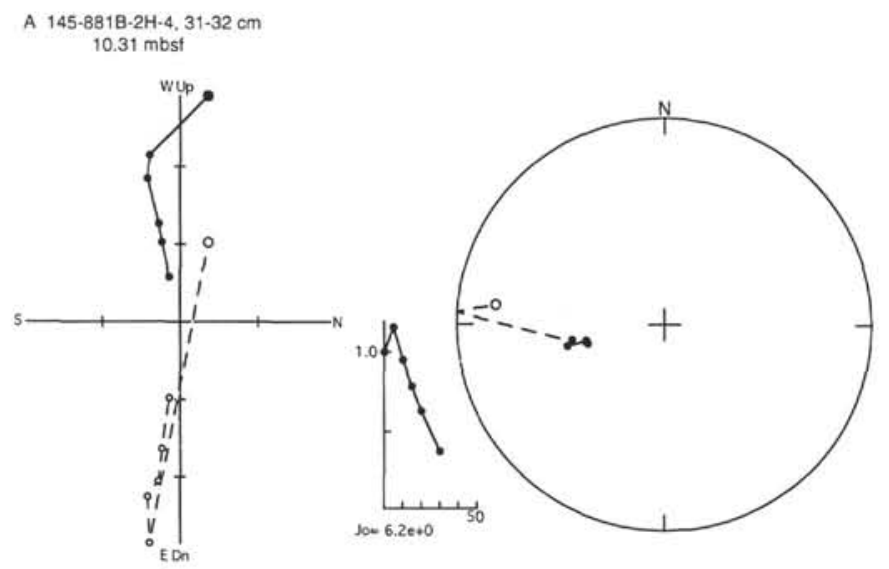

B $145-881 \mathrm{~B}-7 \mathrm{H}-3.30-31 \mathrm{~cm}$
$56.3 \mathrm{mbsf}$

C $145-881 \mathrm{~B}-6 \mathrm{H}-3,30-31 \mathrm{~cm}$

$46.8 \mathrm{mbst}$
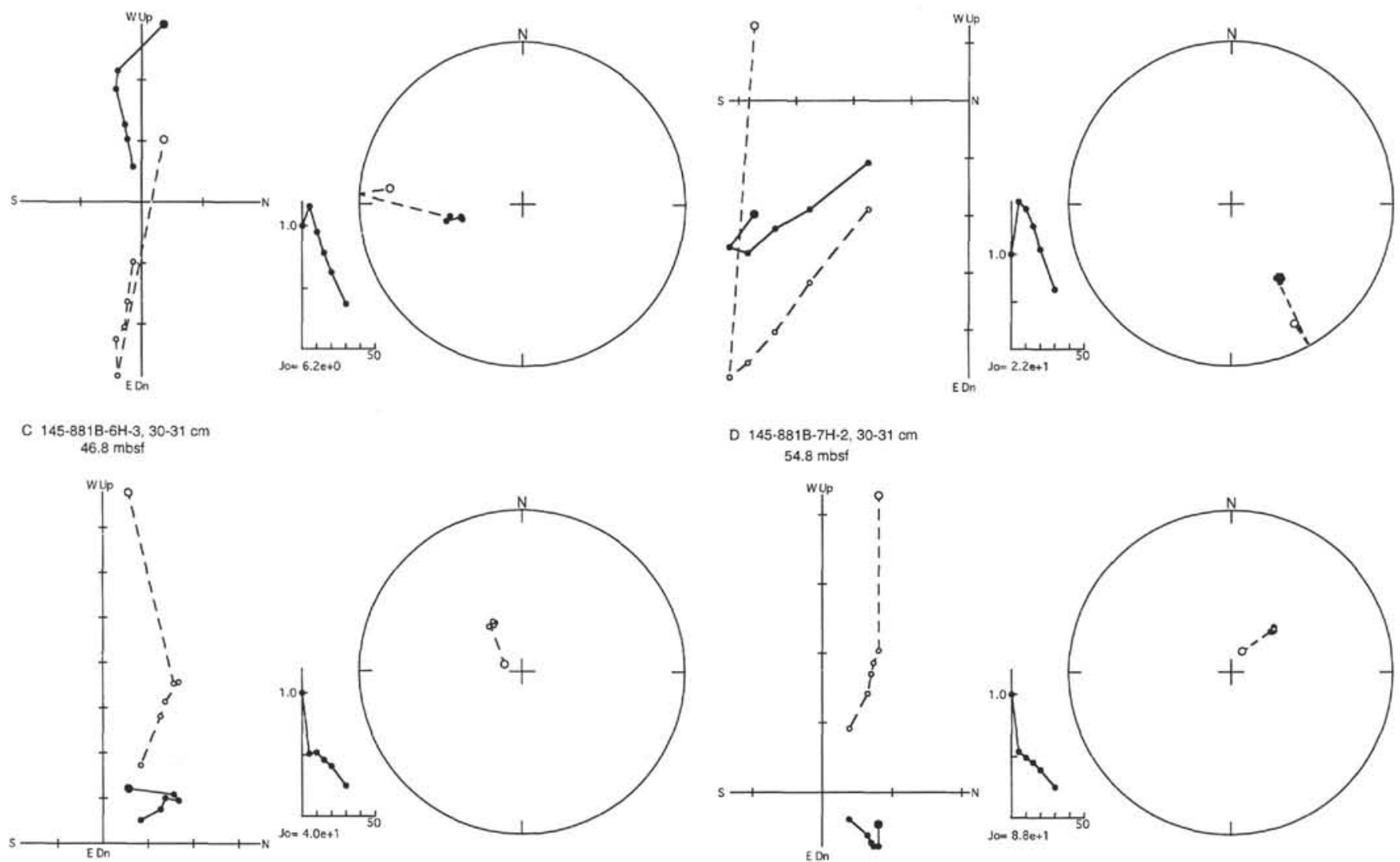

Figure 5. Representative vector component plots from discrete sample demagnetizations from Hole 881B. For the vector component plots, open (solid) symbols represent projections onto the vertical (horizontal) plane. For the equal-area projections, open (solid) symbols indicate an upward (downward)-pointing vector. These conventions apply to all subsequent plots of this type. $\mathbf{A}$ and $\mathbf{B}$ are examples of normal polarity samples. $\mathbf{C}$ and $\mathbf{D}$ are examples of reversed polarity samples.

sediments lie in the age range from 8 to $4 \mathrm{Ma}$ and, based on susceptibility correlations with Site 884 (Fig. 10), the three thick zones of normal polarity between 300 and 360 mbsf in Hole $882 \mathrm{~A}$ are interpreted to represent the lower three normal subchrons in the Gilbert Reversed Chron (Fig. 10; Chron C3n.2n-C3.4n; i.e., the Nunivak, Sidufjall, and Thvera subchrons). The upper normal subchron in the Gilbert (C3n.In; i.e., the Cochiti Subchron), which occurs during the low-intensity diatom dump zone, appears to be partially recorded by the sediments in Hole 882A (Figs. 9 and 10). The susceptibility correlation, in this case, allows an interpretation to be made of the poorquality magnetic results in this zone at Site 882 . Considering the interpretation shown in Figure 10, it is clear that the time interval represented in the last $100 \mathrm{~m}$ of Hole $882 \mathrm{~A}$ is short and that the sedimentation rate is, therefore, substantial. Depths to the polarity boundaries are given down to the Gauss/Matuyama boundary in Table 2.

\section{Site $\mathbf{8 8 3}$}

Pass-through NRM intensities and whole-core susceptibility results are shown in Figure 11 for Hole 883B. As with Sites 881 and 882 , remanence intensities and susceptibilities are high in the upper part of the sequence and gradually decrease to a depth of $87 \mathrm{mbsf}$ in Hole $883 \mathrm{~B}$ and $90 \mathrm{mbsf}$ in Hole $883 \mathrm{C}$, at which point the values of these parameters abruptly decrease by more than one order of magni- tude (i.e., at the boundary between Subunits IA and IB). The remanence intensity does not increase again until about $720 \mathrm{mbsf}$ (Fig. 11). A lithologic boundary (between Subunits IVA and IVB) occurs at 740 mbsf (Fig. 2), where increased susceptibilities and increased cumulative ash thicknesses occur. Despite the increase in remanence intensity, XCB drilling disturbances at these depths renders it difficult to interpret the whole-core magnetization directions.

With the exception of disturbed and diatom-dominated parts of the sequence, the sediments appear to record stable normal and reversed field directions in the upper $90 \mathrm{~m}$ of Holes $883 \mathrm{~B}$ and $883 \mathrm{C}$ (Fig. 12; the axial dipole field inclination is $\pm 68.3^{\circ}$ at a latitude of $\left.51^{\circ} 33^{\prime} \mathrm{N}\right)$. A weak reversed polarity drilling overprint was commonly observed at Site 883. Demagnetization of single samples shows that the overprint can be removed at peak alternating fields of 5-10 mT (Fig. 13). Some indications of unstable remanence are seen in stratigraphically localized regions where discrete sample demagnetizations do not support the normal polarity events seen in the whole-core measurements (Fig. 13D, -E). As with parts of the record at Site 882, we infer that samples from these zones are unstably magnetized. The normal polarity events may represent remagnetization of the whole core by a possible small DC bias field present in the demagnetization coils of the pass-through system. The individual sample results were again helpful in discriminating polarity events that are artifacts of remagnetization from stably magnetized polarity zones in the whole- 
Table 1. Depths of polarity chron boundaries in Holes 881B, 881C, and 881D.

\begin{tabular}{|c|c|c|c|c|}
\hline \multirow[b]{2}{*}{ Polarity boundary } & \multicolumn{3}{|c|}{ Depth (mbsf) } & \multirow{2}{*}{$\begin{array}{l}\text { Age (Ma) } \\
\text { (CK92) }\end{array}$} \\
\hline & Hole 881B & Hole $881 \mathrm{C}$ & Hole 881D & \\
\hline Matuyama/Brunhes & $\begin{array}{c}46.50 \\
(6 \mathrm{H}-3,0 \mathrm{~cm})\end{array}$ & $\begin{array}{c}48.10 \\
(6 \mathrm{H}-5,30 \mathrm{~cm})\end{array}$ & & 0.780 \\
\hline Termination Jaramillo & $\begin{array}{c}55.05-58.1 \\
(7 \mathrm{H}-2,55 \mathrm{~cm}, \text { to } 7 \mathrm{H}-4,60 \mathrm{~cm})\end{array}$ & $\begin{array}{c}57.60 \\
(7 \mathrm{H}-5,30 \mathrm{~cm})\end{array}$ & & 0.984 \\
\hline Onset Jaramillo & $\begin{array}{c}61.70 \\
(7 \mathrm{H}-6,120 \mathrm{~cm})\end{array}$ & $\begin{array}{c}62.5 \text { or } 66.7 \\
(8 \mathrm{H}-2,20 \mathrm{~cm} \text {, or } 8 \mathrm{H}-4,140 \mathrm{~cm})\end{array}$ & & 1.049 \\
\hline Termination Olduvai & $\begin{array}{c}103.60 \\
(12 \mathrm{H}-3,10 \mathrm{~cm})\end{array}$ & $\begin{array}{c}105(?) \\
(12 \mathrm{H}-5,20 \mathrm{~cm} ?)\end{array}$ & & 1.757 \\
\hline Onset Olduvai & $\begin{array}{c}108.95 \\
(12 \mathrm{H}-6,95 \mathrm{~cm})\end{array}$ & $\begin{array}{c}109.9 ? \\
(13 \mathrm{H}-2,10 \mathrm{~cm} ?)\end{array}$ & & 1.983 \\
\hline Termination Réunion & $\begin{array}{c}117.8-119.8 \\
(13 \mathrm{H}-6,30 \mathrm{~cm})\end{array}$ & $\begin{array}{c}123.05 \\
(14 \mathrm{H}-4,75 \mathrm{~cm})\end{array}$ & & 2.197 \\
\hline Onset Réunion & $\begin{array}{c}125.0 \\
(14 \mathrm{H}-3,150 \mathrm{~cm})\end{array}$ & $\begin{array}{c}127.50 \\
(14 \mathrm{H}-7.70 \mathrm{~cm})\end{array}$ & & 2.229 \\
\hline Termination ' $\mathrm{X}$ '-anomaly & $\begin{array}{c}138.50 \\
(16 \mathrm{H}-1.0 \mathrm{~cm})\end{array}$ & $\begin{array}{c}139.50 \\
(16 \mathrm{H}-2,120 \mathrm{~cm})\end{array}$ & & 2.420 \\
\hline Onset ' $\mathrm{X}$ '-anomaly & $\begin{array}{c}143.70 \\
(16 \mathrm{H}-4,70 \mathrm{~cm})\end{array}$ & $\begin{array}{c}144.40 \\
(16 \mathrm{H}-6,10 \mathrm{~cm})\end{array}$ & & 2.441 \\
\hline Gauss/Matuyama & $\begin{array}{c}164.80 \\
(18 \mathrm{H}-2,130 \mathrm{~cm})\end{array}$ & & $\begin{array}{c}163.0-164.5 \\
(1 \mathrm{H}-6,5 \mathrm{~cm}, \text { to } 2 \mathrm{H}-1,0 \mathrm{~cm})\end{array}$ & 2.600 \\
\hline Termination Kaena & & & $\begin{array}{c}178.20 \\
(3 \mathrm{H}-3,120 \mathrm{~cm})\end{array}$ & 3.054 \\
\hline Onset Kaena & & & $\begin{array}{c}181.50 \\
(3 \mathrm{H}-5,150 \mathrm{~cm})\end{array}$ & 3.127 \\
\hline Termination Mammoth & & & $\begin{array}{c}184.20 \\
(4 \mathrm{H}-1,70 \mathrm{~cm})\end{array}$ & 3.221 \\
\hline Onset Mammoth & & & $\begin{array}{c}186.20 \\
(4 \mathrm{H}-2,120 \mathrm{~cm})\end{array}$ & 3.325 \\
\hline Gilber/Gauss & & & $\begin{array}{c}197.9-201.5 \\
(5 \mathrm{H}-4,40 \mathrm{~cm} \text {, to } 5 \mathrm{H}-6,100 \mathrm{~cm})\end{array}$ & 3.553 \\
\hline Termination Cochiti & & & $210.80(6 \mathrm{H}-6,80 \mathrm{~cm})$ & 4.033 \\
\hline
\end{tabular}

Note: CK92 = Cande and Kent (1992).

core magnetostratigraphy. Aside from the problematic depths indicated in Figure 13, the discrete sample demagnetizations are in almost perfect agreement with the whole-core results (Fig. 12).

Data from Hole 883B are in good agreement with those from Hole $883 \mathrm{C}$ (Fig. 12) over depths where demagnetizations were performed on both cores ( $0-100 \mathrm{mbsf})$. The Matuyama/Brunhes polarity transition occurs at approximately the same depth in Holes 883B (33.3 mbsf) and $883 \mathrm{C}$ ( $35.05 \mathrm{mbsf})$. The records from Site 883 reveal a simple magnetostratigraphy that can be readily matched to the polarity time scale of Cande and Kent (1992) as far back as the Gauss/ Matuyama boundary at approximately $84 \mathrm{mbsf}$. We have not been able to confirm the presence of the Réunion event at Site 883. Two normal events are evident between the Gauss/Matuyama boundary and the Olduvai Subchron in the whole-core measurements (Fig. 12); however, discrete sample data indicate that the lower event is an artifact of magnetization. We tentatively correlate the upper normal polarity zone with the Réunion event, however, we have not confirmed this with discrete sample data. Between about $90 \mathrm{mbsf}$ and the bottoms of Holes $883 \mathrm{~B}$ and $883 \mathrm{C}$, the data are of insufficient quality to warrant magnetostratigraphic interpretation. However, we have again attempted to use a susceptibility correlation with Site 884 to aid interpretation in this zone (Fig. 14). The sediments in the diatom-rich zone have an even weaker signal than those at Site 882 . However, the correlation gives an indication of the location of the Gilbert/Gauss boundary and preceding subchrons to C3An. In (Fig. 14). This correlation demonstrates that sedimentation rates in excess of $10 \mathrm{~cm} / \mathrm{k} . \mathrm{y}$. occurred in the period between 4.8 and 3.55 m.y. Possible locations of the normal subchrons within the Gilbert Chron, based on susceptibility correlation with Site 884 , are also indicated in Figure 14.
Depths to the polarity boundaries recognized in Holes $883 \mathrm{~B}$ and $883 \mathrm{C}$ are given down to the Gauss/Matuyama boundary in Table 3.

\section{Site 884}

At Site 884, NRM intensities and susceptibilities are higher at all depths than those at Sites 882 and 883 (Fig. 15). This difference is particularly marked in the intermediate depth regions (e.g., Site 883, $87-650$ mbsf; Fig. 11), which have weaker intensities at Sites 882 and 883 because of dilution by large concentrations of diatoms. For example, at Site 884 , between 200 and 600 mbsf, remanence intensities are about one order of magnitude higher than at equivalent depths at Site 883 . This result is consistent with the generally higher clay contents found at all depths at Site 884 compared to the nearby (shallower) sites (882 and 883) on the Detroit Seamount. Site 884 lies in deeper water on the Meiji Tongue, which is considered to be a drift deposit where deep thermohaline currents are responsible for the long-term, long-distance transport of sediment (Scholl et al., 1977; Mammerickx, 1985). At Site 884, clay fluxes in the upper Miocene to Pliocene sequence are as high as in the Pleistocene at the other sites. This attests to the significance of clay transport and focusing by bottom currents at depths greater than $3300 \mathrm{~m}$ (i.e., at depths greater than that of Site 882).

An additional contrast to the other sites is that there is no abrupt decrease in intensity with depth at the top of the diatom-rich zone at Site 884 , but rather a gradual decrease between about 100 and 150 mbsf (Fig. 15). However, the remanence and susceptibility curves show overall variations that are similar to those seen at other sites with a zone of low values between 200 and 600 mbsf, followed by a 

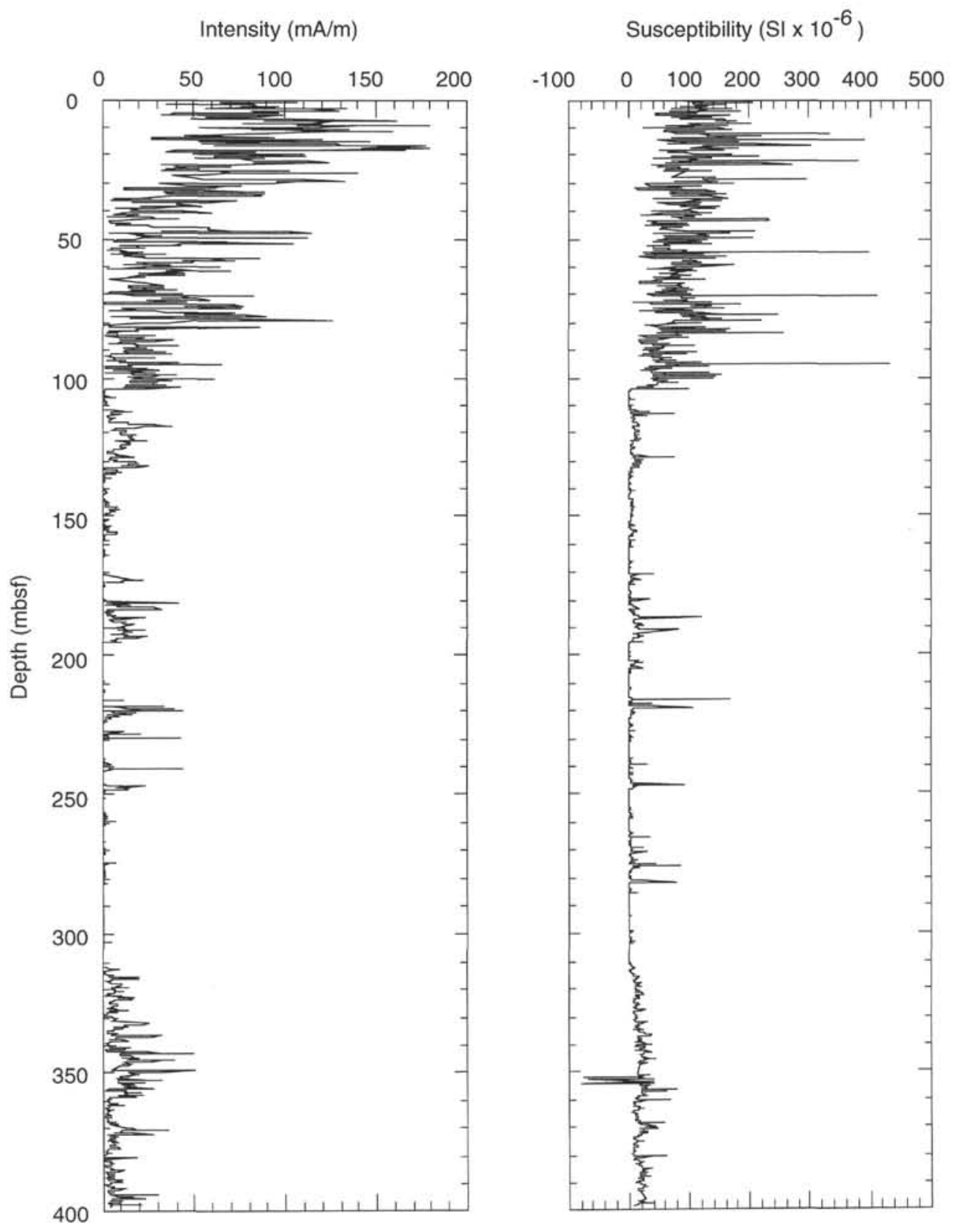

Figure 6. NRM intensities after demagnetization at $15 \mathrm{mT}$, compared with the whole-core susceptibility from Hole $882 \mathrm{~A}$.

gradual increase between 600 and 700 mbsf to values comparable to those in the top $100 \mathrm{~m}$ of the sediment column. These changes coincide with lithologic Subunits IA (initial high intensity and susceptibility), Subunits IB to ID (all with relatively low intensity and susceptibility), and Unit II (high intensity and susceptibility), respectively (Fig. 2).

As at other sites, a reversed polarity drilling overprint was commonly observed at Site 884 (Fig. 16). Demagnetization of single samples shows that this overprint is readily removed at peak alternating fields of 5-10 mT. However, in contrast to the other sites, the discrete samples held a measurable and apparently stable remanence throughout most of Hole 884B (Fig. 16). These samples confirm the polarity zonation determined from the whole-core measurements for the upper $380 \mathrm{~m}$ of Hole 884B (Fig. 17). A comparison of the whole-core measured inclinations (after demagnetization at $15 \mathrm{mT}$ ) with data from discrete samples is shown in Figure 17.
For the continuous whole-core data, the directional results from sediment cored with the XCB are noisier than those recovered by the $\mathrm{APC}$ method. The nature of the noise introduced by $\mathrm{XCB}$ coring can be seen in the record from Section 145-884C-24X-3 (Fig. 18). The periodic signal in inclination, declination, and intensity delineates zones of twisting, separated by zones of breakage where the sediment failed. Both inclination and declination have been significantly modified by this deformation process. However, the polarity of the sediment appears to have remained largely intact. Support for this conclusion is found in results from Hole $884 \mathrm{C}$, which agree remarkably well with those from Hole 884B, and show little depth offset (Fig. 19). With the exception of poor recovery near the termination of the Olduvai Subchron, overlaps from Hole $884 \mathrm{C}$ make up for zones of poor recovery in Hole $884 \mathrm{~B}$, so that continuous coverage was obtained to a depth of 350 mbsf. Sediments from Holes $884 \mathrm{~B}$ and $884 \mathrm{C}$ were drilled with the XCB method from within the Olduvai Subchron, 


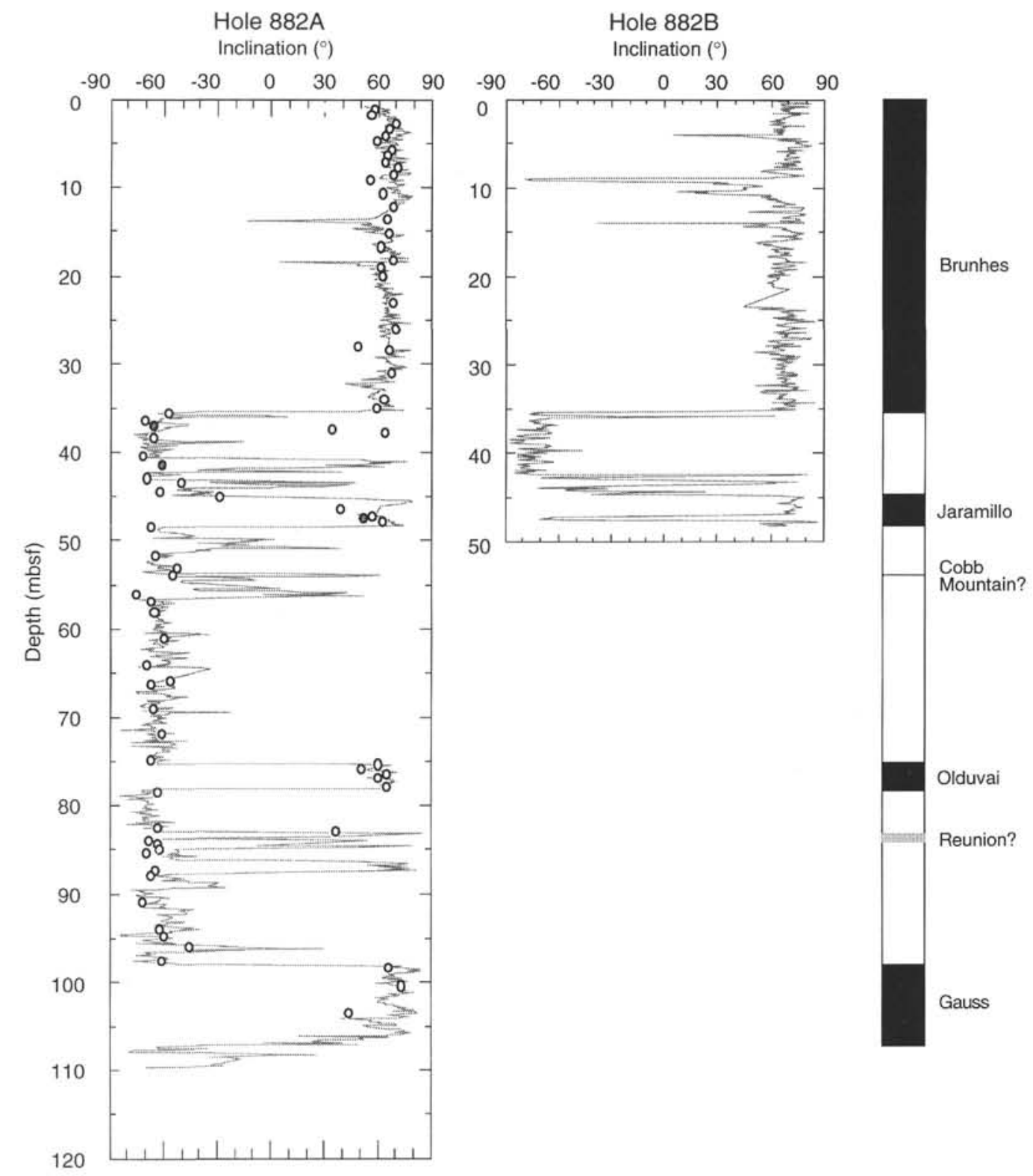

Figure 7. Comparison of whole-core measurements of inclinations measured at $15 \mathrm{mT}$ from Holes $882 \mathrm{~A}$ and $882 \mathrm{~B}$ (solid line) with results from least-squares line fits to demagnetization results from discrete samples between 15 and $40 \mathrm{mT}$ (open circles) from Hole $882 \mathrm{~A}$. The magnetostratigraphic interpretation is shown on the right.

from $87.3 \mathrm{mbsf}$ and $78.4 \mathrm{mbsf}$, respectively, to the bottom of each hole. With the exception of disturbed sediment, stable normal and reversed field directions are recorded between 0 and at least $600 \mathrm{mbsf}$ in Hole $884 \mathrm{~B}$ (the axial dipole field inclination is $\pm 68.3^{\circ}$ at a latitude of $51^{\circ} 33^{\prime} \mathrm{N}$ ). In the age versus depth curve, based on the magnetostratigraphy, shown in Figure 20, a significantly low sedimentation rate occurs at $70-120 \mathrm{mbsf}$, which includes the Olduvai Subchron. This feature is discussed further in our description of results from Site 887.

Core 145-884B-40X (353.6 mbsf) marks the transition from soft sediment to more lithified material in Hole 884B. Below this level, the sediment was broken into drilling biscuits by XCB coring. Despite this deformation, the cores again appear to have retained a coherent magnetostratigraphy, at least as far down as Core 145-884B-
$65 \mathrm{X}$ ( $603.8 \mathrm{mbsf})$. This indicates that, on average, the drilling biscuits have retained their vertical orientation.

Results from Holes $884 \mathrm{~B}$ and $884 \mathrm{C}$ provide almost $600 \mathrm{~m}$ of coherent magnetostratigraphy, with an almost continuous record for the first 350 mbsf. The composite magnetostratigraphy from Holes $884 \mathrm{~B}$ and $884 \mathrm{C}$, and its correlation to the polarity time scale of Cande and Kent (1992), is shown in Figure 19. A clear interpretation is possible from $0 \mathrm{Ma}$ to the top of Chron 5Ar. $1 \mathrm{n}(12.6 \mathrm{Ma})$ at about $580 \mathrm{mbsf}$. Although the paleomagnetic results appear to provide a continuous record over this interval, with a coherent picture of sedimentation rate variation (Fig. 20), biostratigraphic results suggest a hiatus or compressed zone below the base of Chron $5 n$ (about $510 \mathrm{mbsf}$ ). The duration of the hiatus and its precise location are uncertain and better definition should be achieved with further, more detailed, biostrati- 
A

$882 \mathrm{~A}-5 \mathrm{H}-3,125-127 \mathrm{~cm}$ $41.55 \mathrm{mbsf}$

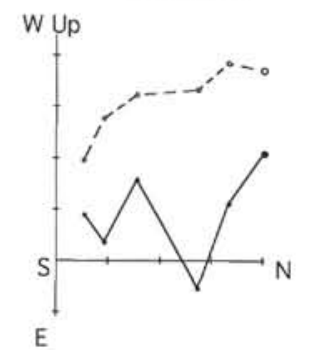

Dn

B

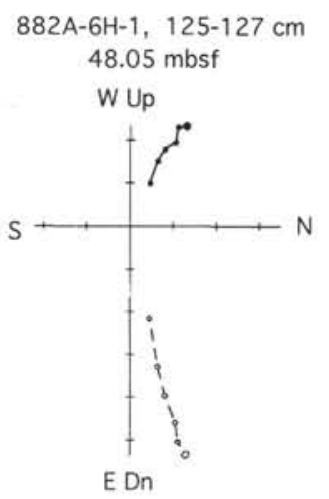

C $882 \mathrm{~A}-5 \mathrm{H}-1,125-127 \mathrm{~cm}$ $38.55 \mathrm{mbsf}$

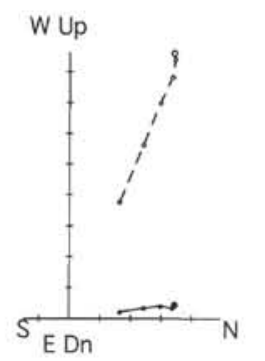

D $882 \mathrm{~A}-10 \mathrm{H}-2,125-127 \mathrm{~cm}$ $83.15 \mathrm{mbsf}$

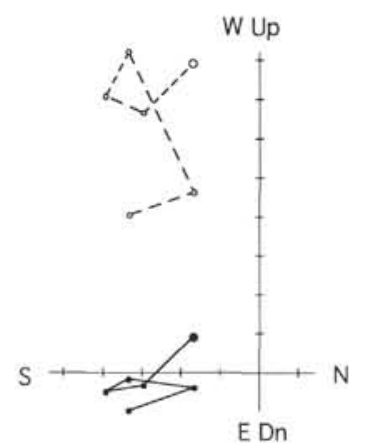

Figure 8. Examples of vector component plots from Hole 882A. A and D illustrate unstable behavior that may be responsible for the spurious events in the whole-core results. $\mathbf{B}$ and $\mathbf{C}$ illustrate stable behavior, which is predominant for the depth interval shown in Figure 7.

graphic work in this zone. However, a second possible interpretation of the magnetostratigraphy (Fig. 20 and Table 4) includes a compressed zone at the base of Chron $5 \mathrm{n}$.

\section{Site $\mathbf{8 8 7}$}

NRM intensities and susceptibilities from pass-through measurements are shown in Figure 21 for Hole 887C. As at other sites from Leg 145, Site 887 is characterized by high remanence and susceptibility values within the top $100 \mathrm{mbsf}$, which decrease abruptly below this depth as the abundance of diatoms increases. In contrast to previous sites, no increase in intensity and susceptibility is evident toward the bottom of the sedimentary sequence. However, values for both NRM intensity and susceptibility remain well within measurable levels. Both curves in Figure 21 clearly show a sharp transition between lithologic Units I and II at 89.5 mbsf (cf. Fig. 2), where there is an almost order of magnitude decrease in susceptibility. A gradual increase in susceptibility coincides with the boundary between lithologic Subunits IIA and IIB at 174 mbsf.

As at earlier sites, a reversed polarity drilling overprint was observed in samples from Hole 887A (Fig. 22). Discrete sample demagnetizations indicate that this overprint is removed by peak alternating fields of 5-10 mT (Fig. 22). Discrete samples held a measurable and apparently stable remanence throughout most of Hole 887, with some exceptions (Fig. 22).

Results from Holes $887 \mathrm{~A}$ and $887 \mathrm{C}$ provide at least $270 \mathrm{~m}$ of coherent and continuous magnetostratigraphy (Fig. 23 and Table 5; the axial dipole field inclination is $\pm 70.3^{\circ}$ at a latitude of $54^{\circ} 22^{\prime} \mathrm{N}$ ). Di-

rectional results from sediments recovered using $\mathrm{XCB}$ coring in Hole $887 \mathrm{~A}$ are noisier than results from sediments recovered using APC coring in Hole $887 \mathrm{C}$. In the intermediate to deep parts of Hole 887A, recovery from $\mathrm{XCB}$ coring was low, whereas at the same depths in Hole 887 C, APC recovery was good (Fig. 23A). The paleomagnetic results from Hole $887 \mathrm{C}$ appear to be of extremely high quality. As a result, below $180 \mathrm{mbsf}$, the magnetostratigraphy was interpreted almost exclusively using whole-core results from Hole $887 \mathrm{C}$. In the upper parts of the sequence (above $180 \mathrm{mbsf}$ ), a continuous magnetostratigraphy was constructed using the results from both Holes $887 \mathrm{~A}$ and $887 \mathrm{C}$. The magnetostratigraphy between 0 and $180 \mathrm{mbsf}$, the means by which it was constructed, and its correlation to the polarity time scale of Cande and Kent (1992) are shown in Figure 23A. The magnetostratigraphy from 180 to $273.8 \mathrm{mbsf}$ is shown in Figure 23B. Depths to polarity boundaries recognized in Holes $887 \mathrm{~A}$ and $887 \mathrm{C}$ are given in Table 5.

Magnetostratigraphic results from Site 887 are extraordinary in their resolution, continuity, and length. A clear interpretation of the magnetostratigraphy is possible from $0 \mathrm{Ma}$ to the top of Chron 5En (18.3 Ma) at about $272 \mathrm{mbsf}$. The record to $18.3 \mathrm{Ma}$ appears to be continuous, with no suggestion of substantial missing time intervals. A detailed and coherent picture of sedimentation rate variation, based on the magnetostratigraphy, is shown in Figure 24. The sedimentation rates near the base of the section are close to $0.5 \mathrm{~cm} / \mathrm{k} . \mathrm{y}$., an order of magnitude lower than the rates near the top of the hole. As at other sites from Leg 145, a low sedimentation rate is evident at about the level including the Olduvai Subchron (60-90 mbsf). Thus, low sedimentation rates near the Olduvai Subchron appear to occur across the entire North Pacific Ocean.

\section{DISCUSSION}

It would not have been possible to obtain the high-quality magnetostratigraphic results outlined in this paper if it were not for the development of new coring techniques that were designed to recover long, continuous, and undisturbed sedimentary records. The results obtained here also demonstrate that XCB rotary drilling at deeper depths seriously compromises the fidelity of the paleomagnetic record (Fig. 18) and that this type of drilling should be avoided, especially when chronological constraints from magnetostratigraphy are crucial to the mission of drilling.

Throughout the North Pacific Ocean, two important changes in mass accumulation rates and flux of major sediment components are apparent: one near the Miocene/Pliocene boundary, the other near the Gauss/Matuyama geomagnetic reversal boundary. The interval beginning at the Miocene/Pliocene boundary at $5.4 \mathrm{Ma}$ and extending to $2.6 \mathrm{Ma}$ (generally lithologic Subunit IB) is consistently dominated by radiolarian-bearing diatom ooze and a dramatic decrease is seen in clay, volcanic ash, and quartz fluxes. The interval beginning at the Gauss/Matuyama boundary at $2.6 \mathrm{Ma}$ and extending to $0 \mathrm{Ma}$ (generally lithologic Subunit IA) is marked by high fluxes of diatoms, clay, volcanic ash, ice-rafted detritus (IRD), and quartz. The diatom ooze of Subunit IB defines a time of extreme silica deposition in the North Pacific Ocean. This episode was observed at all Leg 145 sites and represents a short period of extreme productivity at high latitudes that is associated with an early Pliocene period of climatic amelioration.

Early studies by Conolly and Ewing (1970) and Kent et al. (1971) indicate that a period of deposition of abundant IRD began near the Gauss/Matuyama boundary at 2.6 Ma. However, only three cores from these studies penetrated to the Gauss Chron and lack of deeper recovery precluded investigation of older ice-rafted material. Rea and Schrader (1985) studied ice-rafting in the North Pacific Ocean in cores from the Deep Sea Drilling Project (DSDP), using diatom biostratigraphy as the basis for their chronological framework. They concluded that the onset of significant ice-rafting was coincident with 

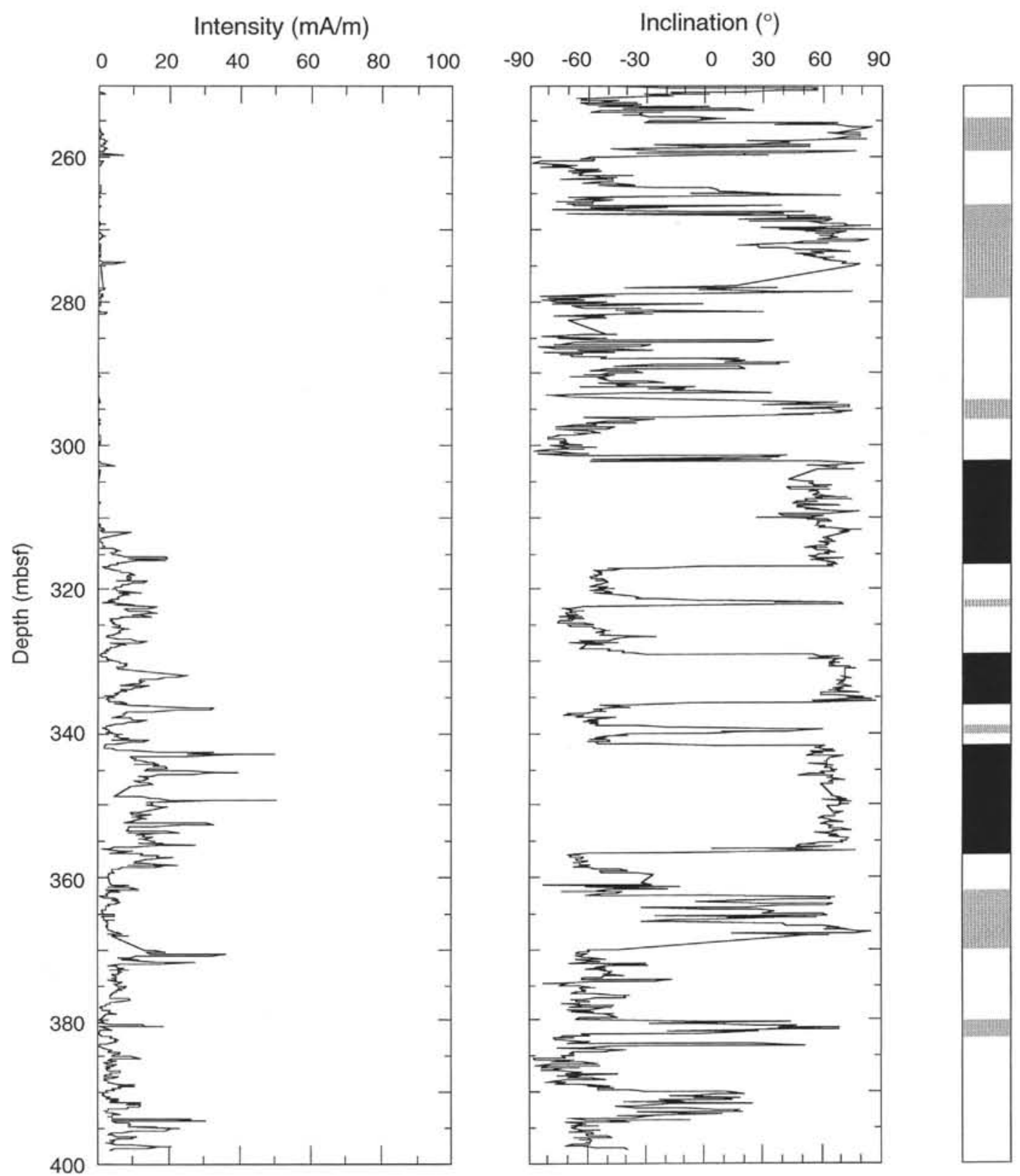

Figure 9. Intensity and inclination of NRM after demagnetization at $15 \mathrm{mT}$ from whole-core measurements between 250 and $400 \mathrm{mbsf}$ in Hole $882 \mathrm{~A}$. The polarity sequence is shown on the right, with gray zones representing poorly defined polarity events that occur in zones of weak remanence intensity.

the onset of glaciation in the North Atlantic Ocean at $2.6 \mathrm{Ma}$, as reported by Shackleton et al. (1984). Dropstones appear consistently at the Leg 145 sites at $2.6 \mathrm{Ma}$, heralding the onset of major glaciation in the Northern Hemisphere. This suggests that the onset of glaciation in the areas feeding the North Pacific Ocean was synchronous with the onset of Laurentide and Fennoscandian glaciation (Rea and Schrader, 1985). Taken together, the Leg 145 drill sites from the northwest Pacific Ocean and Leg 86 drill sites (Heath, Burkle, et al., 1985; Krissek et al., 1985; Krissek, this volume) define the source of northwest Pacific Ocean dropstones to be the Kamchatka Peninsula, as first suggested by Conolly and Ewing (1970). Dropstones are far more abundant in the Gulf of Alaska (Site 887) than in the northwest Pacific Ocean and are of different lithology, confirming the distinctly Alaskan source of IRD (McKelvey et al., this volume), as suggested by Rea and Schrader (1985). The Pacific-wide dropstone record, should therefore permit comparison of the timing and pulses of glaciation in Siberia and North America.

An increase, by more than one order of magnitude, of volcanogenic material near $2.6 \mathrm{Ma}$ in the North Pacific Ocean has also been known for many years (Kennett and Thunnell, 1975; Kennett et al., 1977), however, the Leg 145 sites provide much better-dated sequences for determining the timing of the onset of the northwest $\mathrm{Pa}$ cific portion of this oceanwide volcanic episode.

Increased fluxes of terrigenous clays near $2.6 \mathrm{Ma}$ are also recorded at all of the Leg 145 sites, even though overall sedimentation rates were reduced in the upper parts of the records. An enhanced flux of terrigenous material at the time of onset of significant continental glaciation has been recorded commonly in the North Atlantic and North 
Hole $882 \mathrm{~A}$

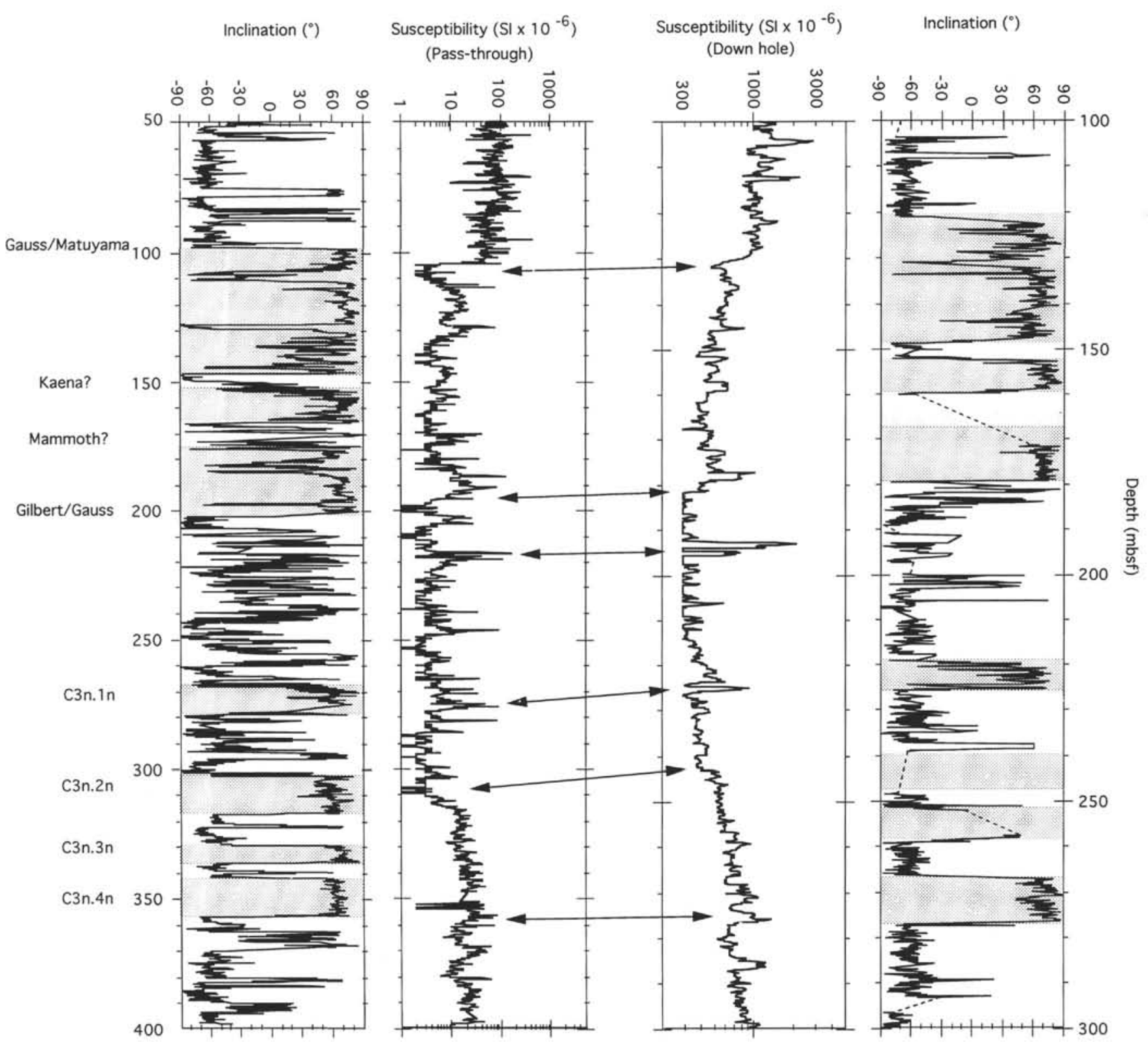

Figure 10. Correlation of susceptibility logs between Holes $882 \mathrm{~A}$ and $884 \mathrm{~B}$ provides a firmer basis for interpretation of the magnetic results from Site 882 . The locations of normal polarity zones identified at Hole $884 \mathrm{~B}$ are transferred to Hole $882 \mathrm{~A}$ using the susceptibility record.

Pacific oceans. The enhanced influx of terrigenous material may be associated with the onset of bottom-current activity, as well as increased eolian input due to increased continental aridity at that time (Janecek and Rea, 1983; Janecek, 1985).

The magnetostratigraphic framework outlined in this paper provides crucial constraints on the dating of paleoceanographic and paleoclimatic events recorded in the sedimentary sequences drilled during Leg 145. Sites 884 and 887 have provided some of the longest continuous-polarity sequences ever obtained in the history of ocean drilling. Rapid accumulation of clay-rich sediments at Site 884 permitted development of a magnetic reversal stratigraphy that is coherent back to the middle Miocene at approximately $12.6 \mathrm{Ma}$. This stratigraphy permits the direct correlation for the first time of the
North Pacific Ocean diatom zonations to the magnetic reversal time scale in sediments older than latest Miocene in age. The magnetic reversal stratigraphy at Site 887 , complete to $18 \mathrm{Ma}$, also provides a framework for calibration of microfossil zonations.

\section{ACKNOWLEDGMENTS}

We are grateful to Ravi Jain, Emily Burns, and Lanhui Wu for conducting many of the single-sample demagnetizations and to Janice Fong for redrafting Figure 2. Cor Langereis provided a helpful review of the original manuscript. APR and KLV gratefully acknowledge assistance from a grant from the U.S. Department of Energy's 

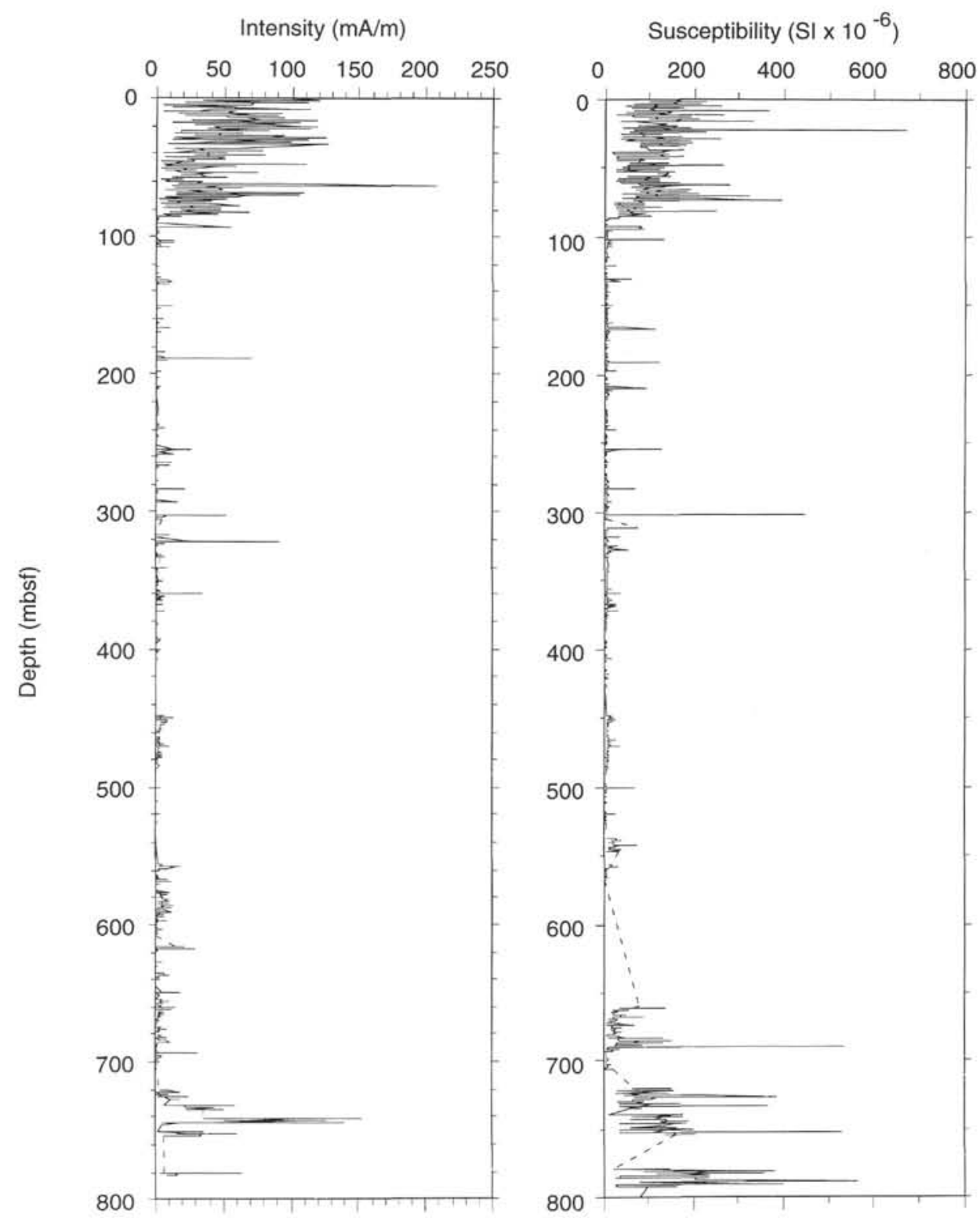

Figure 11. NRM intensities after demagnetization at either $15 \mathrm{mT}$ (0-389.7 mbsf) or $10 \mathrm{mT}$ (389.7-782.2 mbsf) compared with whole-core susceptibilities from Hole 883B.

(DOE) National Institute for Global Environmental Change (NIGEC) through the NIGEC Western Regional Center at the University of California, Davis.

\section{REFERENCES*}

Cande, S.C., and Kent, D.V., 1992. A new geomagnetic polarity time scale for the Late Cretaceous and Cenozoic. J. Geophys. Res., 97:1391713951.

Conolly, J.R., and Ewing, M., 1970. Ice-rafted detritus in northwest Pacific deep-sea sediments. In Hays, J.D. (Ed.), Geological Investigations of the North Pacific. Mem.-Geol. Soc. Am., 126:219-231.

Heath, G.R., Burckle, L.H., et al., 1985. Init. Repts. DSDP, 86: Washington (U.S. Govt. Printing Office).

Janecek, T.R., 1985. Eolian sedimentation in the Northwest Pacific Ocean: a preliminary examination of the data from Deep Sea Drilling Project Sites 576 and 578. In Heath, G.R., Burckle, L.H., et al., Init. Repts. DSDP, 86: Washington (U.S. Govt. Printing Office), 589-603.
Janecek, T.R., and Rea, D.K., 1983. Eolian deposition in the northeast Pacific Ocean: Cenozoic history of atmospheric circulation. Geol. Soc. Am. Bull., 94:730-738.

Kennett, J.P., McBirney, A.R., and Thunnell, R.C., 1977. Episodes of Cenozoic volcanism in the Circum-Pacific region. J. Volcanol. Geotherm. Res., 2:145-163.

Kennett, J.P., and Thunnell, R.C., 1975. Global increase in Quaternary explosive volcanism. Science, 187:497-503.

Kent, D.V., Opdyke, N.D., and Ewing, M., 1971. Climate change in the North Pacific using ice-rafted detritus as a climatic indicator. Geol. Soc. Am. Bull., 82:2741-2754.

Krissek, L.A., Morley, J.J., and Lofland, D.K., 1985. The occurrence, abundance, and composition of ice-rafted debris in sediments from Deep Sea Drilling Project Sites 579 and 580, northwest Pacific. In Heath, G.R., Burckle, L.H., et al., Init. Repts. DSDP, 86: Washington (U.S. Govt. Printing Office), 647-655.

Mammerickx, J., 1985. A deep-sea thermohaline flow path in the northwest Pacific. Mar. Geol., 65:1-19.

Rea, D.K., Basov, I.A., Janecek, T.R., Palmer-Julson, A., et al., 1993. Proc. ODP, Init. Repts., 145: College Station, TX (Ocean Drilling Program). 
Rea, D.K., and Schrader, H., 1985. Late Pliocene onset of glaciation: icerafting and diatom stratigraphy of North Pacific DSDP cores. Palaeogeogr., Palaeoclimatol., Palaeoecol., 49:313-325.

Scholl, D.W., Hein, J.R., Marlow, M., and Buffington, E.C., 1977. Meiji sediment tongue: North Pacific evidence for limited movement between the Pacific and North American plates. Geol. Soc. Am. Bull., 88:1567-1576.

Shackleton, N.J., Backman, J., Zimmerman, H., Kent, D.V., Hall, M.A., Roberts, D.G., Schnitker, D., Baldauf, J.G., Desprairies, A., Homrighausen, R., Huddlestun, P., Keene, J.B., Kaltenback, A.J., Krumsiek, K.A.O., Morton, A.C., Murray, J.W., and Westberg-Smith, J., 1984. Oxygen isotope calibration of the onset of ice-rafting and history of glaciation in the North Atlantic region. Nature, 307:620-623.

Weeks, R.J., Laj, C., Endignoux, L., Fuller, M.D., Roberts, A.P., Manganne, R., Blanchard, E., and Goree, W., 1993. Improvements in long-core mea- surement techniques: applications in palaeomagnetism and palaeoceanography. Geophys. J. Int., 114:651-662.

*Abbreviations for names of organizations and publications in ODP reference lists follow the style given in Chemical Abstracts Service Source Index (published by American Chemical Society).

Date of initial receipt: 5 April 1994

Date of acceptance: 22 December 1994

Ms 145SR-138

Table 2. Depths of polarity chron boundaries in Holes 882A and 882B.

\begin{tabular}{|c|c|c|c|c|c|}
\hline \multirow[b]{2}{*}{ Polarity boundary } & \multicolumn{2}{|c|}{ Hole $882 \mathrm{~A}$} & \multicolumn{2}{|c|}{ Hole 882 B } & \multirow[b]{2}{*}{$\begin{array}{l}\text { Age (Ma) } \\
\text { (CK92) }\end{array}$} \\
\hline & $\begin{array}{l}\text { Core, section } \\
(\mathrm{cm})\end{array}$ & $\begin{array}{l}\text { Depth } \\
\text { (mbsf) }\end{array}$ & $\begin{array}{l}\text { Core, section } \\
(\mathrm{cm})\end{array}$ & $\begin{array}{l}\text { Depth } \\
\text { (mbsf) }\end{array}$ & \\
\hline Matuyama/Brunhes & $4 \mathrm{H}-4,120$ & 35.50 & $5 \mathrm{H}-1,40$ & 35.30 & 0.78 \\
\hline Termination Jaramillo & $5 \mathrm{H}-6,0-52$ & $44.80-45.32$ & $6 \mathrm{H}-2,80$ & 44.70 & 0.98 \\
\hline Onset Jaramillo & $6 \mathrm{H}-2,10$ & 48.40 & & & 1.05 \\
\hline Termination Olduvai & $9 \mathrm{H}-1,10$ & 75.40 & & & 1.76 \\
\hline Onset Olduvai & $9 \mathrm{H}-2,135$ & 78.15 & & & 1.98 \\
\hline Réunion & $9 \mathrm{H}-6,25-85$ & $83.05-83.65$ & & & $2.20-2.23$ \\
\hline Gauss/Matuyama & $11 \mathrm{H}-3,80$ & 98.10 & & & 2.60 \\
\hline
\end{tabular}

Note: CK92 = Cande and Kent (1992). 
Hole 883B

Inclination $\left({ }^{\circ}\right)$
Hole $883 \mathrm{C}$

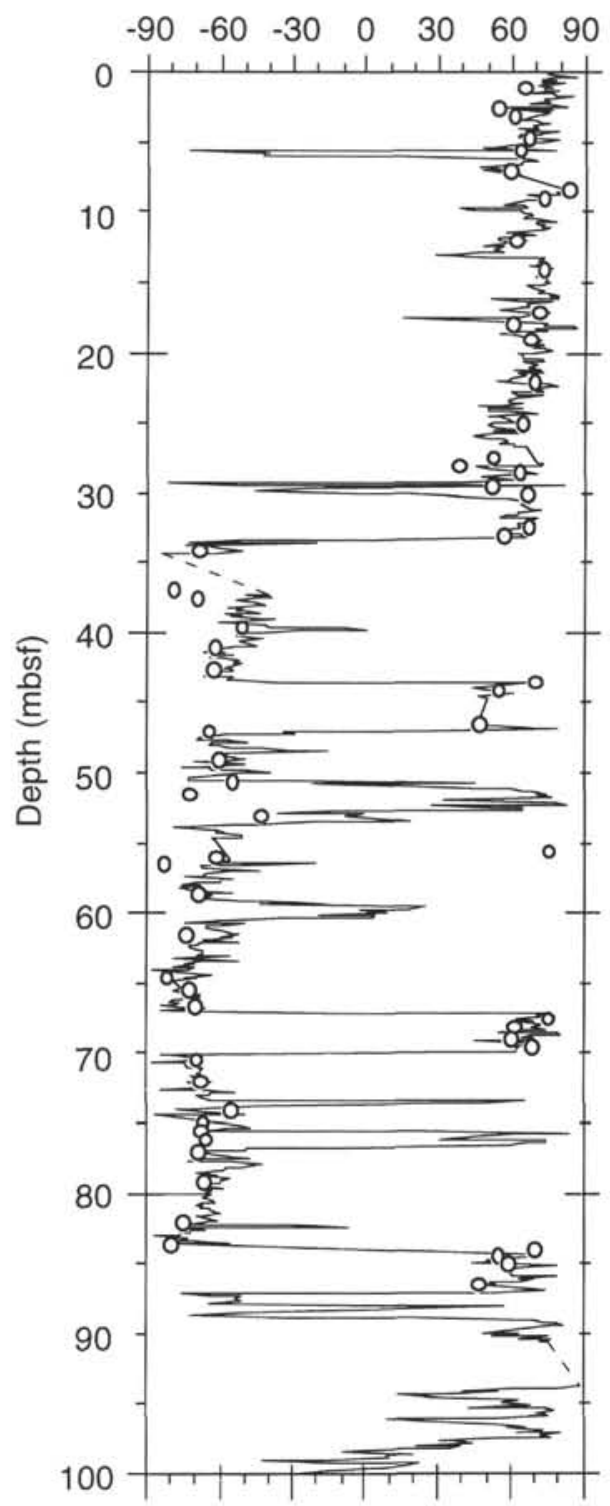

Inclination $\left({ }^{\circ}\right)$

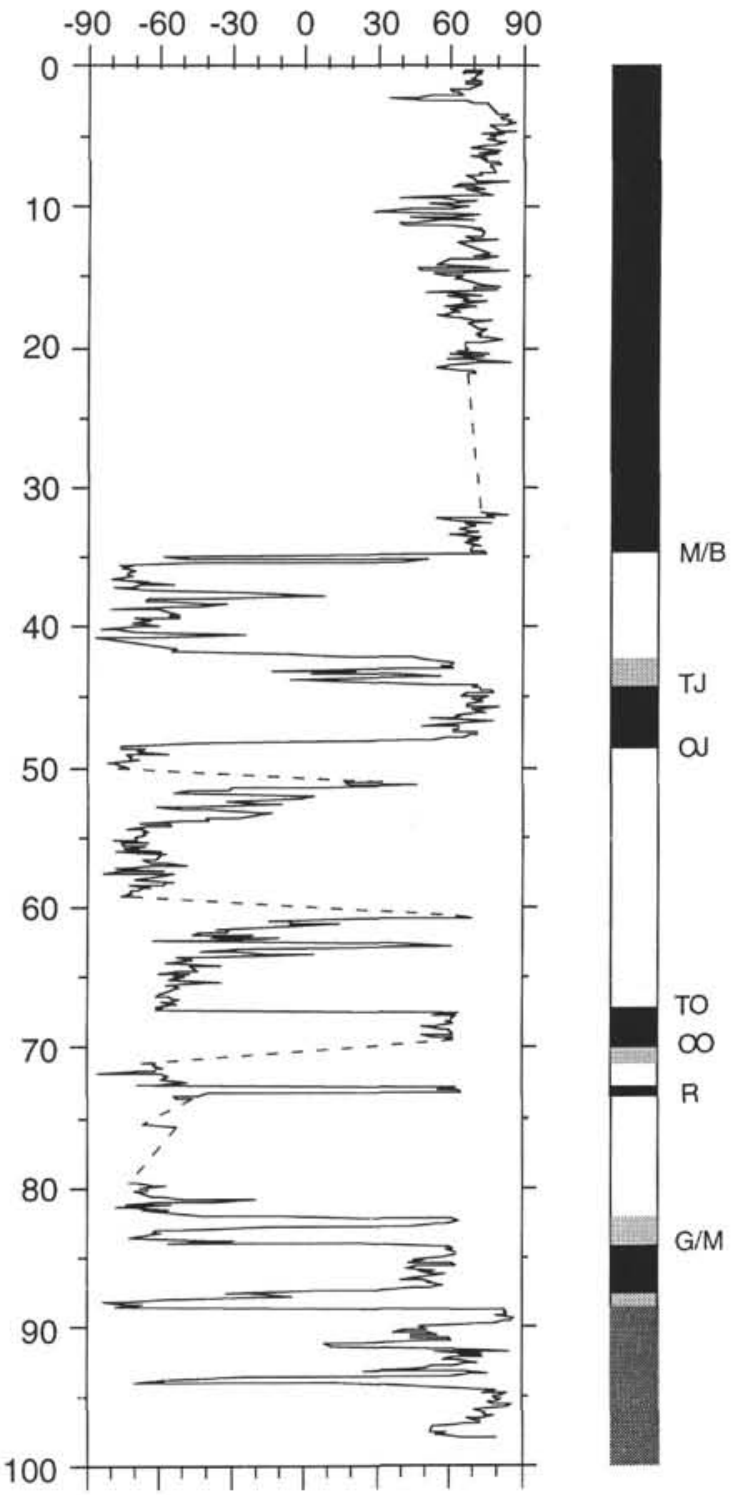

Figure 12. Comparison of whole-core measurements of NRM demagnetized at $15 \mathrm{mT}$ from Holes $883 \mathrm{~B}$ and $883 \mathrm{C}$ (solid lines) with least-squares line fits to demagnetization results from discrete samples between 15 and $40 \mathrm{mT}$ (open circles) from Hole 883B. 
A $145-883 B-5 \mathrm{H}-3-33 \mathrm{~cm}$

$39.73 \mathrm{mbsf}$

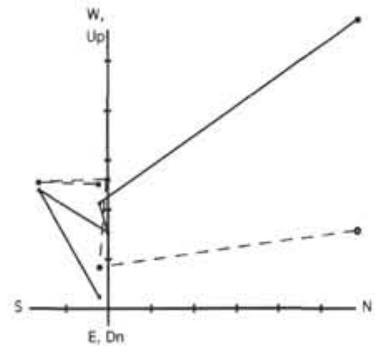

C $145-883 \mathrm{~B}-5 \mathrm{H}-6-33 \mathrm{~cm}$

$44.23 \mathrm{mbsf}$

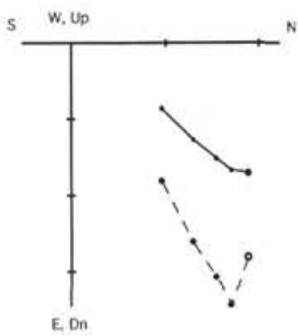

B $145-883 B-5 \mathrm{H}-4-33 \mathrm{~cm}$

$41.23 \mathrm{mbsf}$

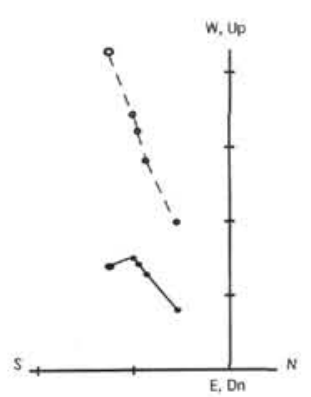

D $145-883 \mathrm{~B}-6 \mathrm{H}-4-125 \mathrm{~cm}$ $51.65 \mathrm{mbsf}$

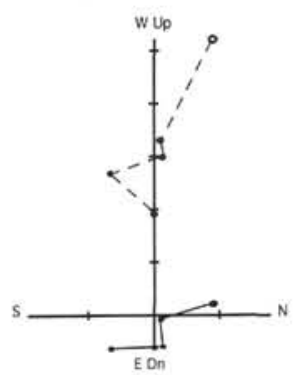

E $145-883 \mathrm{~B}-7 \mathrm{H}-4-33 \mathrm{~cm}$

$60.23 \mathrm{mbsf}$

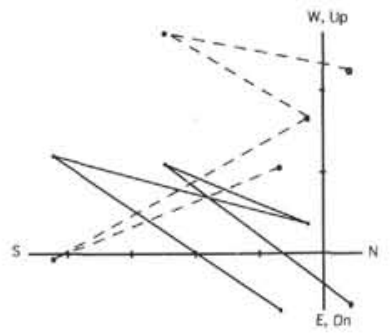

Figure 13. Examples of vector component plots from Hole 883B. A, B, and C illustrate the stable behavior that predominates between 0 and $90 \mathrm{mbsf}$, whereas $\mathbf{D}$ and $\mathbf{E}$ illustrate the behavior most likely responsible for spurious polarity events in the whole-core results. 


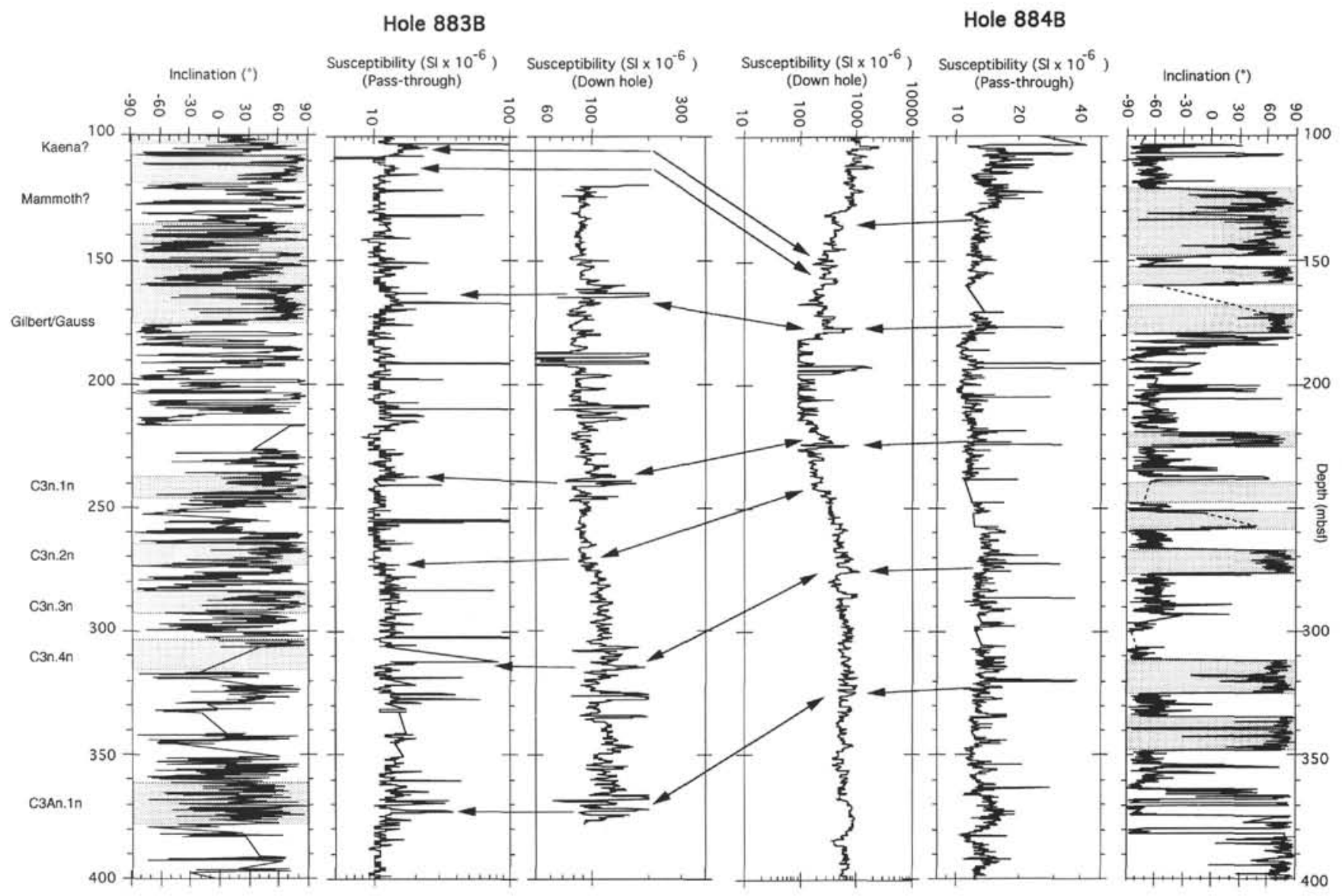

Figure 14. Correlation of susceptibility logs from Holes $883 \mathrm{~B}$ and $884 \mathrm{~B}$. Susceptibility from the pass-through measurements is first matched to the downhole measurements at each site. These correlations are used to transfer polarity information from Hole $884 \mathrm{~B}$ to Hole $883 \mathrm{~B}$ to aid interpretation of the magnetic record of Hole 883B. The estimated locations of the Gilbert/Gauss boundary and several normal subchrons within the Gilbert Chron are indicated.

Table 3. Depths of polarity chron boundaries in Holes 883B and 883C.

\begin{tabular}{|c|c|c|c|}
\hline \multirow[b]{2}{*}{ Polarity boundary } & \multicolumn{2}{|c|}{ Depth (mbsf) } & \multirow{2}{*}{$\begin{array}{c}\text { Age } \\
\text { (Ma) } \\
\text { (CK92) }\end{array}$} \\
\hline & Hole $883 \mathrm{~B}$ & Hole $883 \mathrm{C}$ & \\
\hline Matuyama/Brunhes & $\begin{array}{c}33.30 \\
(4 \mathrm{H}-5,50 \mathrm{~cm})\end{array}$ & $\begin{array}{c}35.05 \\
(5 \mathrm{H}-3.55 \mathrm{~cm})\end{array}$ & 0.780 \\
\hline Termination Jaramillo & $\begin{array}{c}43.50 \\
(5 \mathrm{H}-5,120 \mathrm{~cm})\end{array}$ & $\begin{array}{c}41,85-42.25 \\
(6 \mathrm{H}-1,85-125 \mathrm{~cm})\end{array}$ & 0.984 \\
\hline Onset Jaramillo & $\begin{array}{c}47.00 \\
(6 \mathrm{H}-1,100 \mathrm{~cm})\end{array}$ & $\begin{array}{c}48.35 \\
(6 \mathrm{H}-5,135 \mathrm{~cm})\end{array}$ & 1.049 \\
\hline Termination Olduvai & $\begin{array}{c}67.10 \\
(8 \mathrm{H}-2,70 \mathrm{~cm})\end{array}$ & $\begin{array}{c}67.50 \\
(8 \mathrm{H}-5,150 \mathrm{~cm})\end{array}$ & 1.757 \\
\hline Onset Olduvai & $\begin{array}{c}70.00 \\
(8 \mathrm{H}-4,60 \mathrm{~cm})\end{array}$ & $\begin{array}{c}69.70-71.05 \\
(8 \mathrm{H}-7 \text { to } 9 \mathrm{H}-2)\end{array}$ & 1.983 \\
\hline Termination Réunion & $\begin{array}{c}73.45(?) \\
(8 \mathrm{H}-6.105 \mathrm{~cm} ?)\end{array}$ & $\begin{array}{c}72.90(?) \\
(9 \mathrm{H}-3.40 \mathrm{~cm})\end{array}$ & 2.197 \\
\hline Onset Réunion & $\begin{array}{c}73.80(?) \\
(8 \mathrm{H}-6,140 \mathrm{~cm} ?)\end{array}$ & $\begin{array}{c}73.45(?) \\
(9 \mathrm{H}-3,95 \mathrm{~cm})\end{array}$ & 2.229 \\
\hline Gauss/Matuyama & $\begin{array}{c}83.70-84.30 \\
(9 \mathrm{H}-7 \text { to } 10 \mathrm{H}-1)\end{array}$ & $\begin{array}{c}84.00 \\
(10 \mathrm{H}-4,50 \mathrm{~cm})\end{array}$ & 2.600 \\
\hline
\end{tabular}

Note: CK92 = Cande and Kent (1992). 

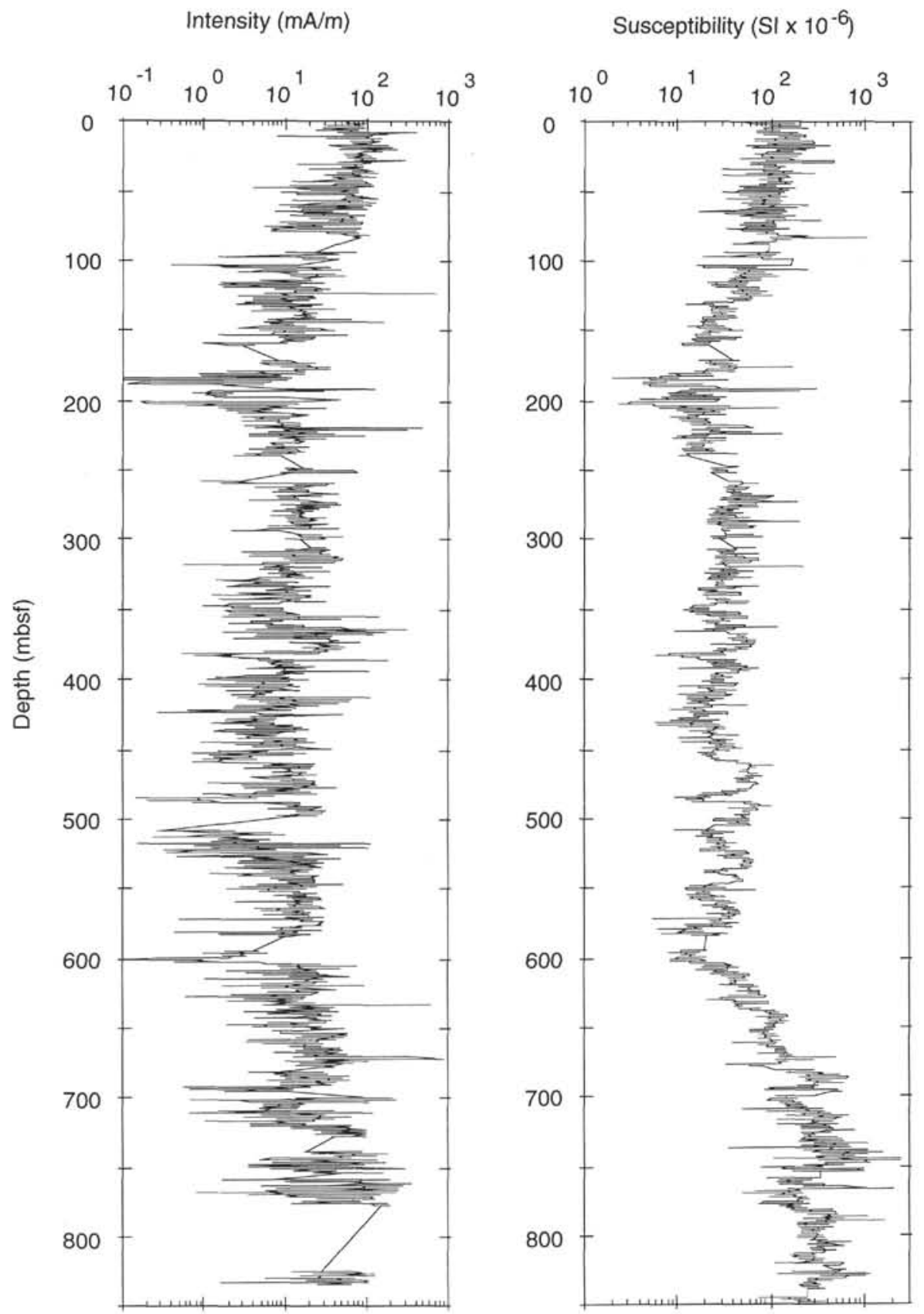

Figure 15. NRM intensities after demagnetization at $15 \mathrm{mT}$ compared with whole-core magnetic susceptibilities from Hole 884B. 
R.J. WEEKS ET AL.

A $145-884 B-5 H-5-125 \mathrm{~cm}$

42.75 mbsf

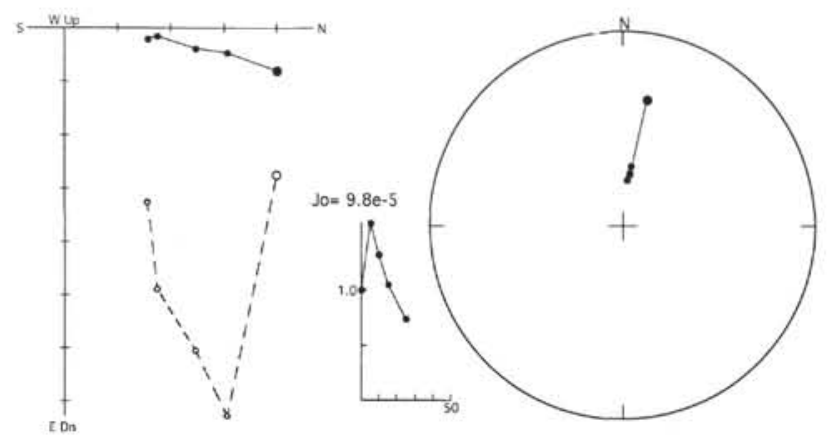
C $145-884 \mathrm{~B}-12 \mathrm{X}-1-60 \mathrm{~cm}$
$87.90 \mathrm{mbsf}$
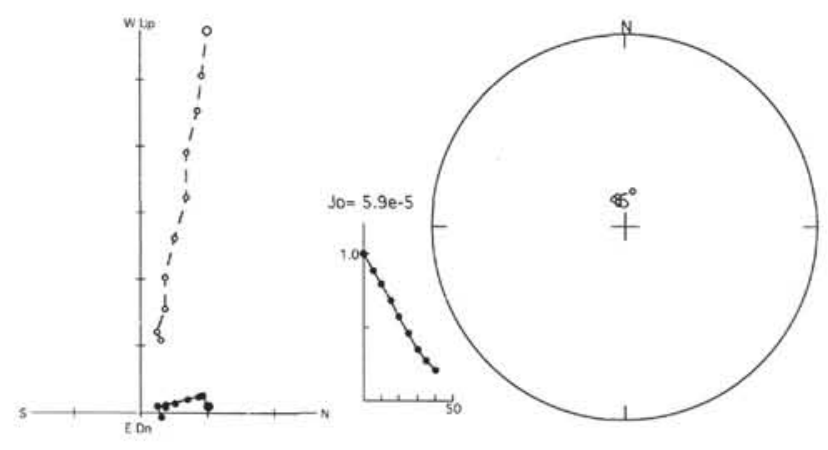

B $145-8848-29 x-1-68 \mathrm{~cm}$ 248.28 mbsf

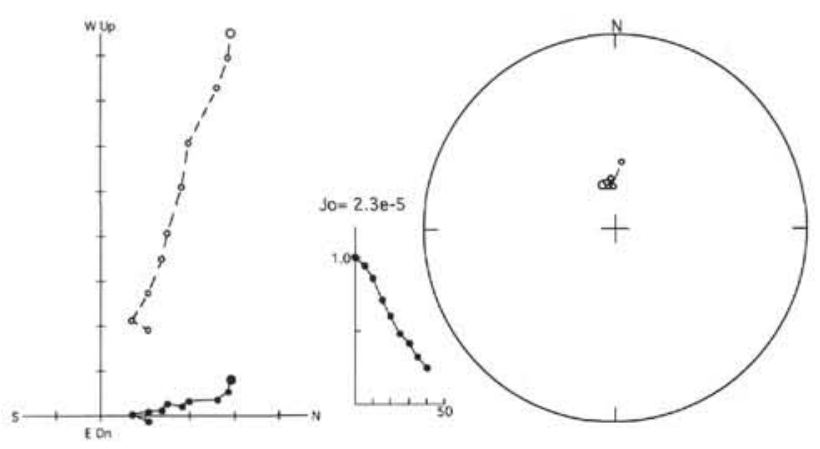

D $145-8848-36 X-1-33 \mathrm{~cm}$ 315.63 mbsf

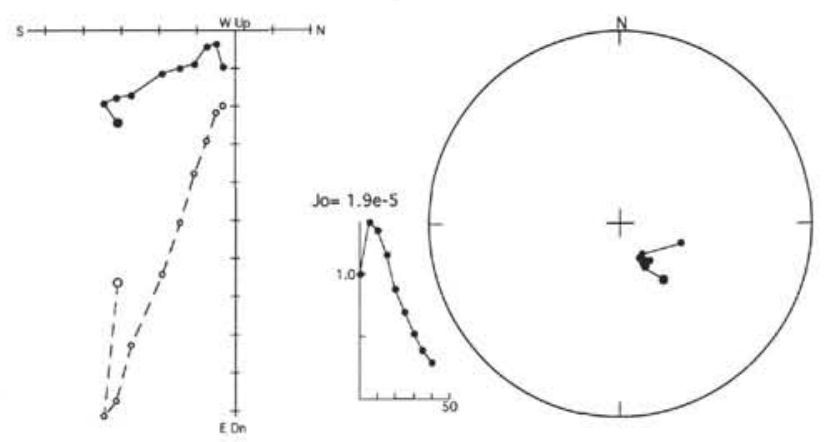

Figure 16. Representative vector component plots from discrete sample demagnetization from Hole $884 \mathrm{~B}$.

510 

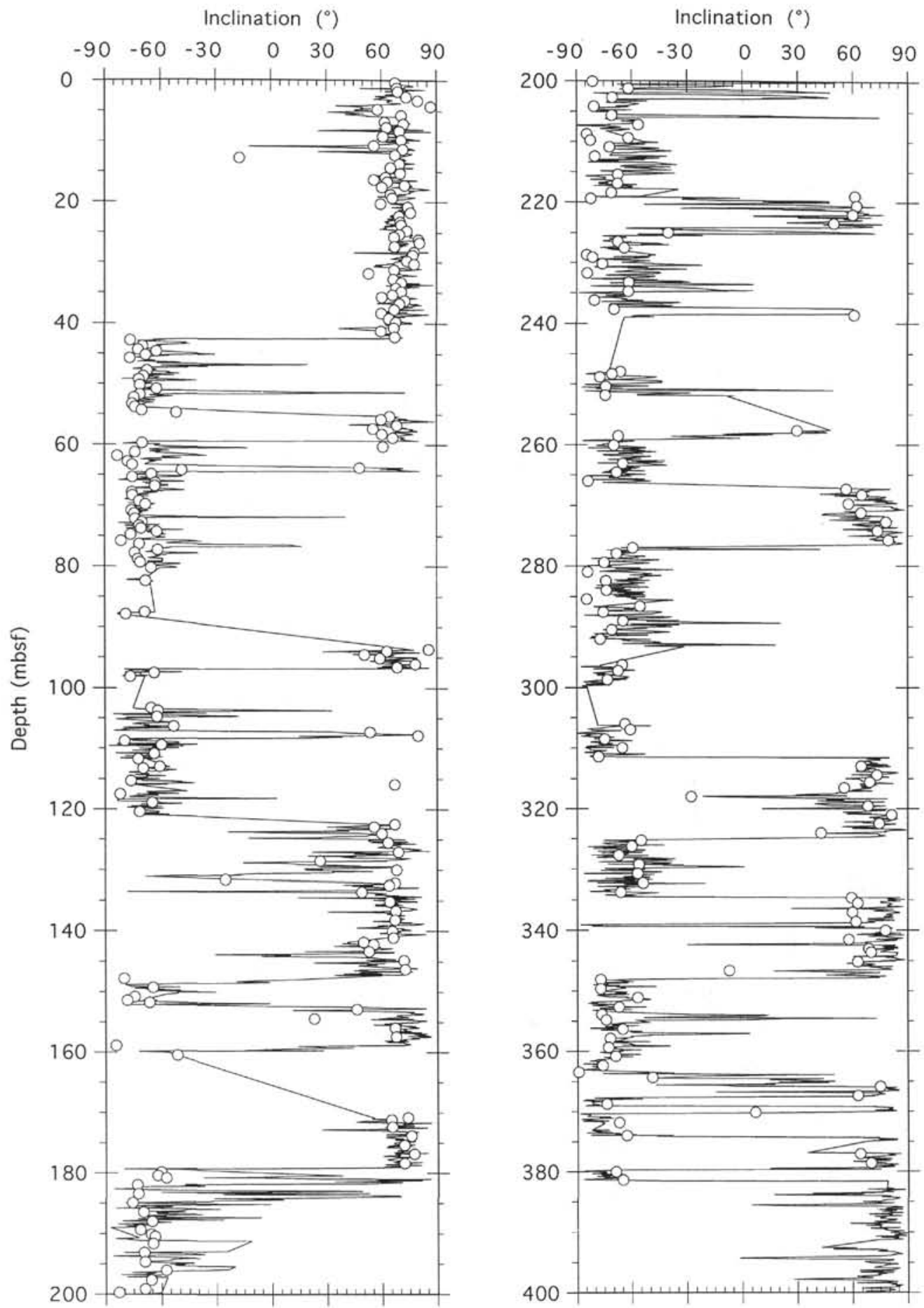

Figure 17. Whole-core measurements of inclination, after 15-mT demagnetization, from Hole 884B, compared with inclinations obtained from least-squares line fits to demagnetization results from discrete samples between 15 and $40 \mathrm{mT}$ (open symbols). 


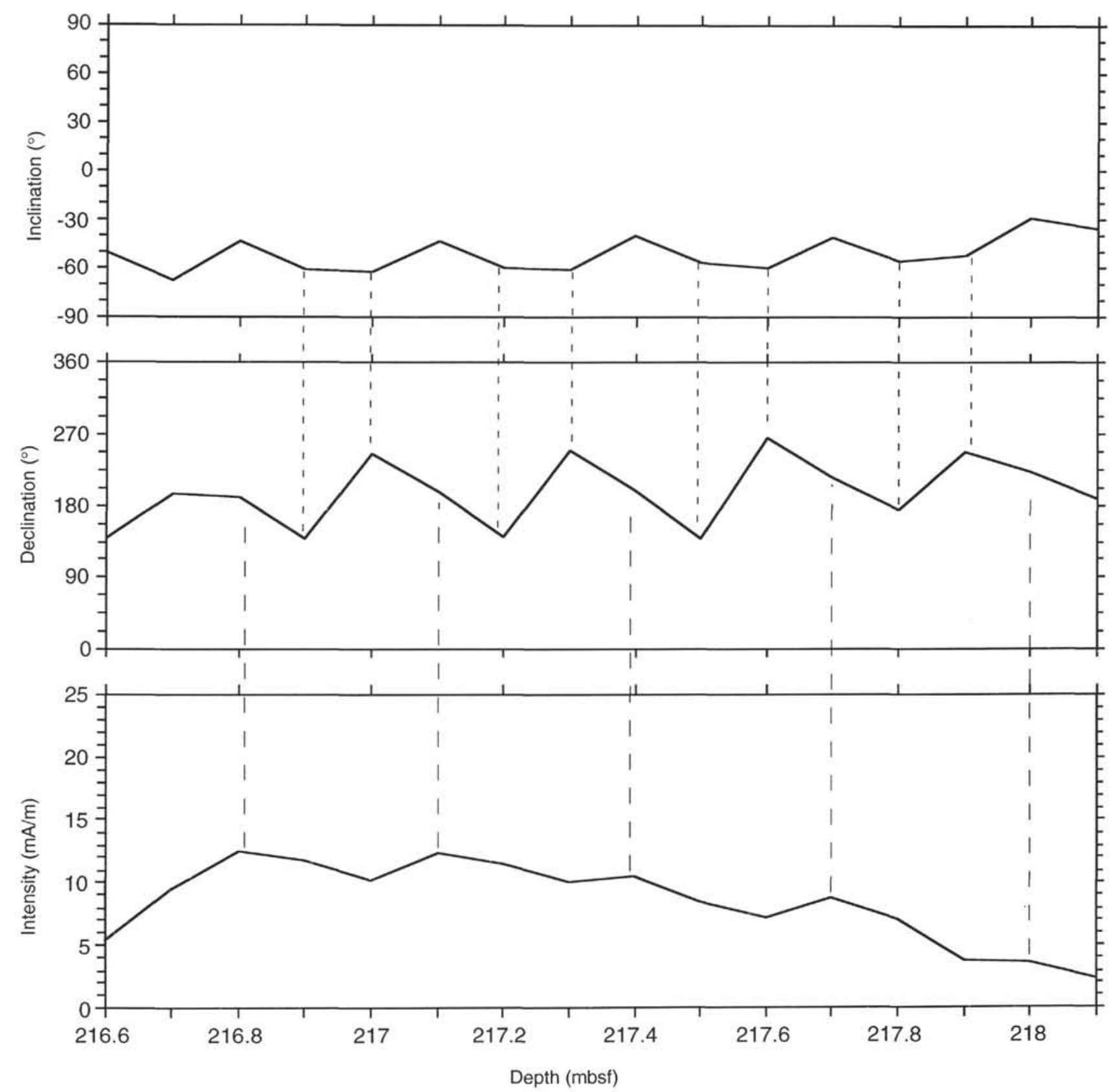

Figure 18. Inclination, declination, and NRM intensity from Section 145-884C-24X-3. The directional and intensity results show a periodic variation produced by drilling deformation associated with XCB drilling. The core apparently broke into 20 - to $30-\mathrm{cm}$ sections, which were deformed by twisting before failure as the drill penetrated the sediment. 


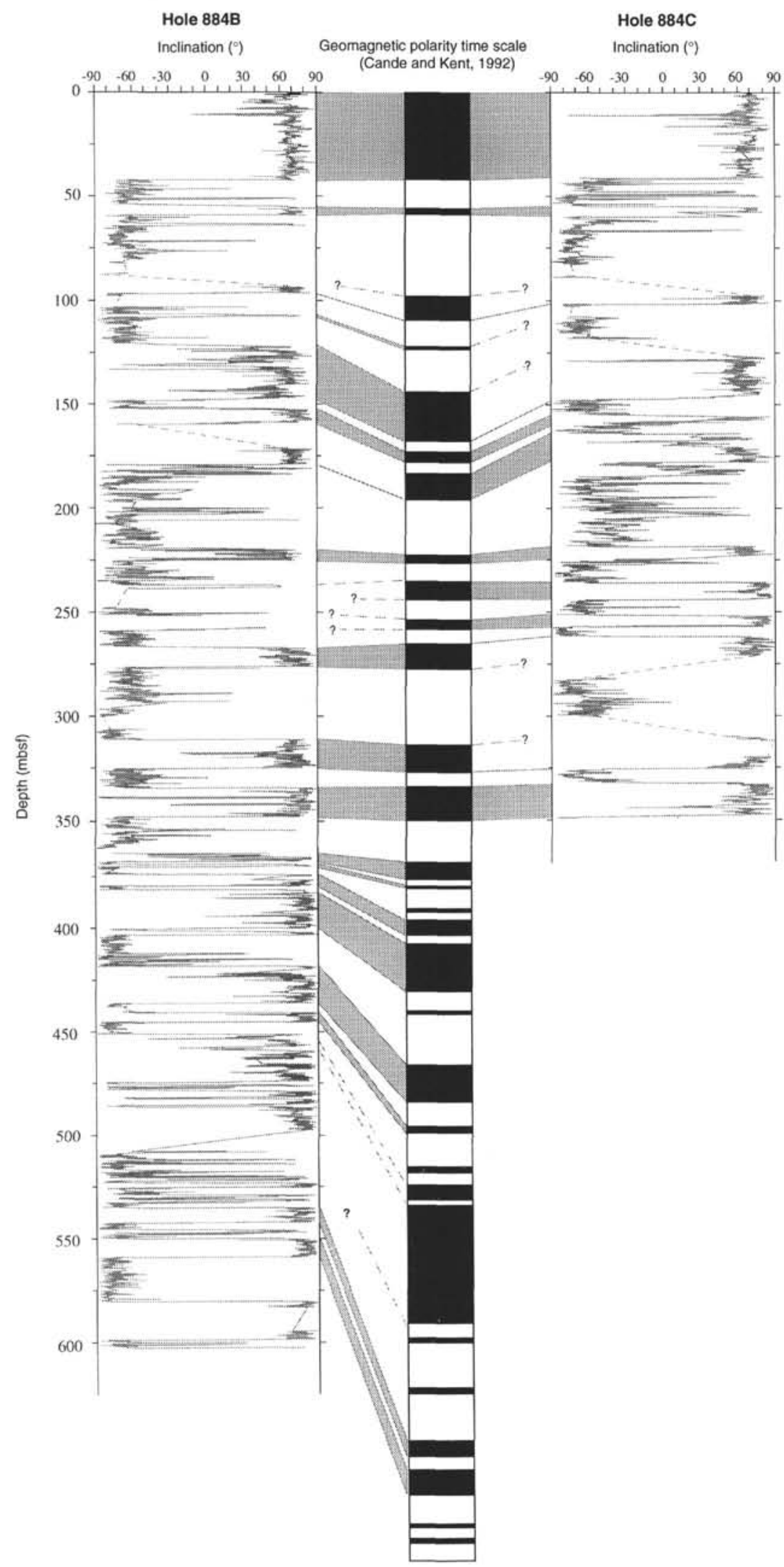

Figure 19. Magnetic inclination records, after 15-mT demagnetization, from Holes $884 \mathrm{~B}$ and $884 \mathrm{C}$. The magnetostratigraphic interpretation is shown in the center where the gray zones connect periods of normal polarity to their location on the time scale of Cande and Kent (1992). Changes in the slope of the gray zones indicate changes in sedimentation rate with respect to the linear time scale. Depths to polarity boundaries are shown in Table 4 with respect to the chron nomenclature of Cande and Kent (1992). 
A

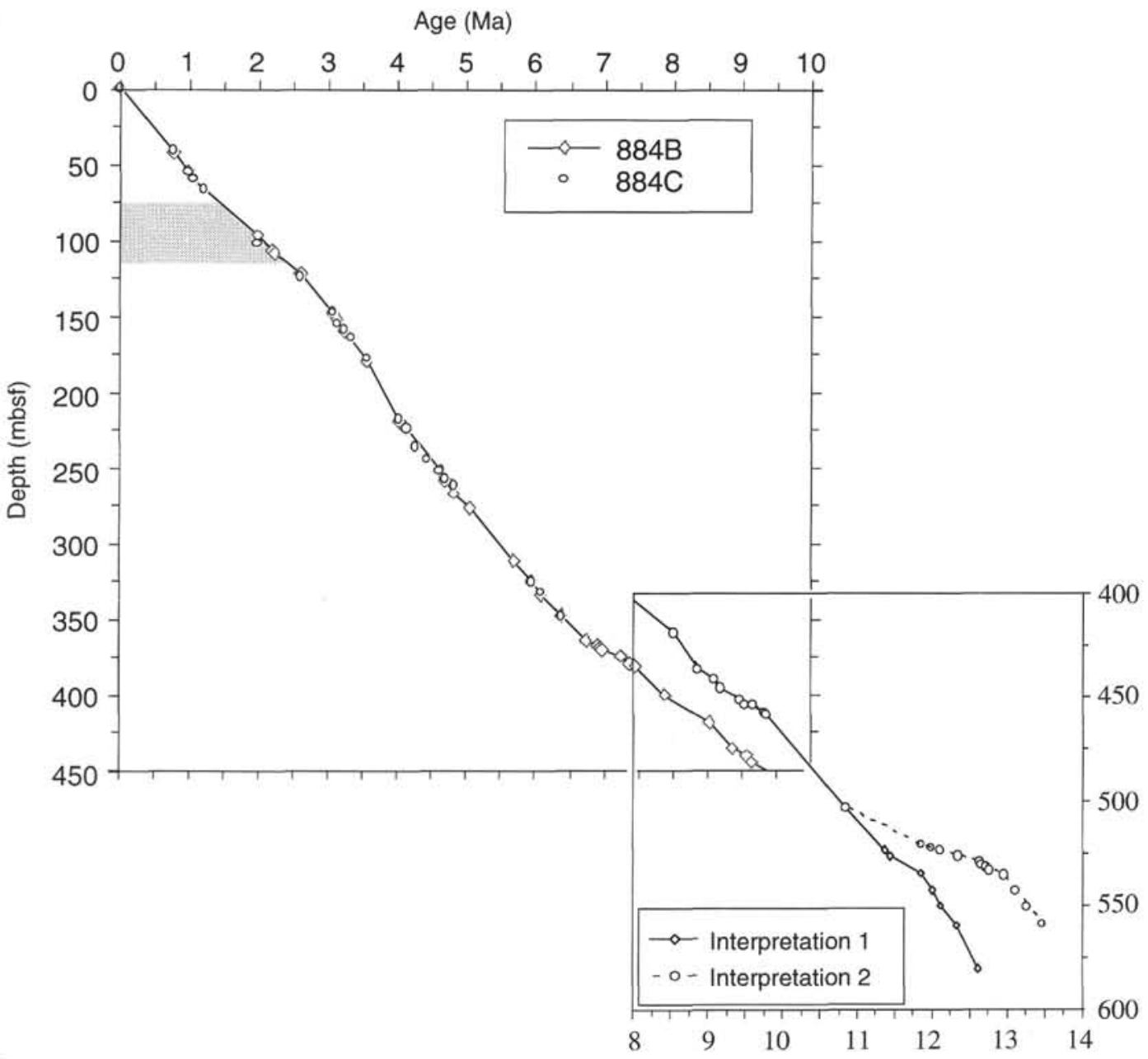

B

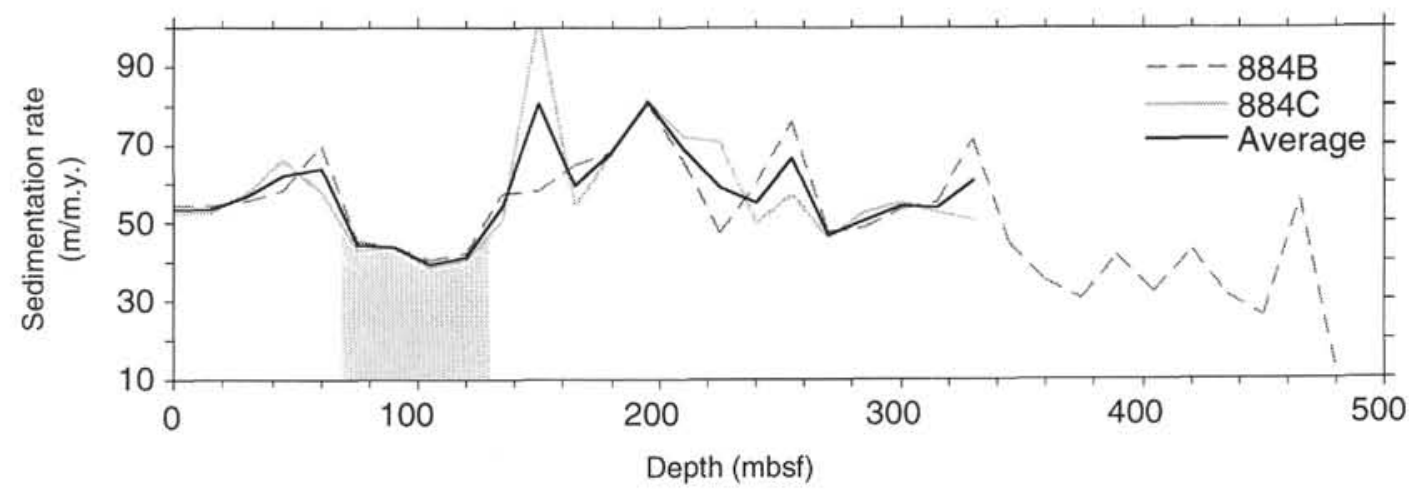

Figure 20. Plots of age vs. depth (A) and sedimentation rate vs. depth (B) for Site 884. Rates were calculated for both Holes $884 \mathrm{~B}$ and $884 \mathrm{C}$. The average of the two holes is shown as the solid line. Two interpretations are shown for the lower part of the record (see text). 
Table 4. Depths of polarity chron boundaries in Holes 884B and $884 \mathrm{C}$.

\begin{tabular}{|c|c|c|c|c|c|c|}
\hline \multirow[b]{2}{*}{$\begin{array}{l}\text { Polarity } \\
\text { boundary }\end{array}$} & \multirow[b]{2}{*}{$\begin{array}{l}\text { Age } \\
(\mathrm{Ma})\end{array}$} & \multicolumn{2}{|l|}{ Hole $884 \mathrm{~B}$} & \multicolumn{2}{|c|}{ Hole $884 \mathrm{C}$} & \multirow[b]{2}{*}{$\begin{array}{c}\text { Interpretation } 2 \\
\text { Depth (mbsf) }\end{array}$} \\
\hline & & $\begin{array}{l}\text { Depth } \\
\text { (mbsf) }\end{array}$ & Notes & $\begin{array}{l}\text { Depth } \\
\text { (mbsf) }\end{array}$ & Notes & \\
\hline $\mathrm{Cln}$ & 0.780 & 42.50 & & 41.10 & & \\
\hline \multirow[t]{2}{*}{ Clr.ln } & 0.984 & $54.00-55.10$ & & 55.00 & & \\
\hline & 1.049 & 59.40 & & 59.70 & & \\
\hline \multirow[t]{2}{*}{ CIr.2r-1n } & 1.201 & & & 66.15 & & \\
\hline & 1.212 & & & 66.60 & & \\
\hline \multirow[t]{2}{*}{$\mathrm{C} 2 \mathrm{n}$} & 1.757 & & & & & \\
\hline & 1.983 & 96.90 & $\mathrm{cb}$ & 101.90 & & \\
\hline \multirow[t]{2}{*}{$\mathrm{C} 2 \mathrm{r} . \mathrm{In}$} & 2.197 & 107.10 & & & & \\
\hline & $\begin{array}{l}2.229 \\
2.600\end{array}$ & $\begin{array}{l}108.20 \\
30-12250\end{array}$ & ch & $11850-12700$ & ch & \\
\hline C2An.In & 3.054 & 148.10 & $\mathrm{cb}$ & $147.00-147.80$ & co & \\
\hline C $2 A n \cdot 2 n$ & 3.127 & 152.35 & & $154.50-156.00$ & $\mathrm{cb}$ & \\
\hline & 3.221 & $159.50-159.70$ & & $158.50-159.50$ & & \\
\hline C2An.3n & 3.325 & & & 164.4 & & \\
\hline & 3.553 & 179.20 & & 178.0 & & \\
\hline C $3 n . I n$ & 4.033 & 219.65 & & 218.45 & & \\
\hline & 4.134 & 224.20 & & 224.50 & & \\
\hline C $3 n .2 n$ & 4.265 & & $\mathrm{~g}$ & 235.90 & & \\
\hline & 4.432 & & $\mathrm{~g}$ & 244.25 & & \\
\hline C $3 n \cdot 3 n$ & 4.611 & $252.10(?)$ & $\mathrm{cb}+\mathrm{g}$ & $251.50-252.40$ & $\mathrm{cb}$ & \\
\hline & 4.694 & $258.40(?)$ & $\mathrm{cb}+\mathrm{g}$ & 256.90 & & \\
\hline$C 3 n .4 n$ & 4.812 & $266.30-267.20$ & $\mathrm{cb}$ & $261.80-261.90$ & $\mathrm{cb}$ & \\
\hline & 5.046 & $276.50-276.90$ & $\mathrm{cb}$ & & $\mathrm{g}$ & \\
\hline C3An.1n & 5.705 & 311.55 & & & $\mathrm{~g}$ & \\
\hline & 5.946 & $324.80-325.20$ & $\mathrm{cb}$ & 325.70 & & \\
\hline C 3 An.2n & 6.078 & 334.50 & $\mathrm{cb}$ & 332.40 & & \\
\hline & 6.376 & 348.0 & & 348.20 & $\mathrm{cb}$ & \\
\hline C3Bn & 6.744 & $364.00-364.60$ & & & & \\
\hline & 6.901 & 367.60 & & & & \\
\hline C3Br. In & 6.946 & 369,10 & & & & \\
\hline & 6.981 & 370.25 & & & & \\
\hline $\mathrm{C} 3 \mathrm{Br} .2 \mathrm{n}$ & 7.153 & & & & & \\
\hline & 7.187 & & & & & \\
\hline C4n.In & 7.245 & 374.20 & & & & \\
\hline & 7.376 & 379.65 & & & & \\
\hline C $4 n \cdot 2 n$ & 7.464 & 381.50 & & & & \\
\hline & 7.892 & 400.20 & & & & \\
\hline C4r.In & 8.047 & & & & & \\
\hline & 8.079 & & & & & \\
\hline C4An & 8.529 & 418.45 & & & & \\
\hline & 8.861 & 436.15 & & & & \\
\hline C4Ar.In & 9.069 & 440.65 & & & & \\
\hline & 9.149 & 445.20 & & & & \\
\hline C 4 Ar.2n & 9.428 & $451.10(?)$ & & & & \\
\hline & 9.491 & $453.10(?)$ & & & & \\
\hline C5n.1n & 9.592 & $453.50(?)$ & & & & \\
\hline & 9.735 & $457.30(?)$ & & & & \\
\hline C. $5 n .2 n$ & 9.777 & $458.00-459.50(?)$ & & & & 458.00 \\
\hline C $5 n \cdot 2 n-1$ & 10.065 & 478.0 & & & & \\
\hline C. $5 n \cdot 2 n-2$ & 10.330 & 481.0 & & & & \\
\hline C $5 n \cdot 2 n-3$ & 10.595 & 485.0 & & & & \\
\hline & 10.834 & $498.0-507.00$ & & & & \\
\hline C5r.In & 10.940 & & & & & \\
\hline & 10.989 & & & & & \\
\hline C5r.2n & 11.378 & 523.00 & & & & \\
\hline & 11.434 & 526.00 & & & & \\
\hline C5An.In & 11.852 & 534.50 & & & & 520.70 \\
\hline & 12.000 & 542.50 & & & & 522.10 \\
\hline C5An.2n & 12.108 & 550.00 & & & & 523.00 \\
\hline & 12.333 & 559.00 & & & & 525.50 \\
\hline C5Ar.In & 12.618 & 580.00 & & & & 528.50 \\
\hline & 12.649 & & & & & 530.00 \\
\hline C5Ar.2n & 12.718 & & & & & 531.00 \\
\hline & 12.764 & & & & & 532.50 \\
\hline C5AAn & 12.941 & & & & & 535.00 \\
\hline & 13.094 & & & & & 542.30 \\
\hline $\mathrm{C} 5 \mathrm{ABn}$ & 13.263 & & & & & 550.00 \\
\hline & 13.476 & & & & & 559.00 \\
\hline $\mathrm{C} 5 \mathrm{ACn}$ & 13.674 & & & & & \\
\hline & 14.059 & & & & & \\
\hline
\end{tabular}

Notes: Ages are after Cande and Kent (1992). The annotation "cb" indicates that a polarity transition occurred in a core break; "g" indicates a core gap. Below Chron 5n, a second possible interpretation is given for Hole $884 \mathrm{~B}$ magnetostratigraphy. 


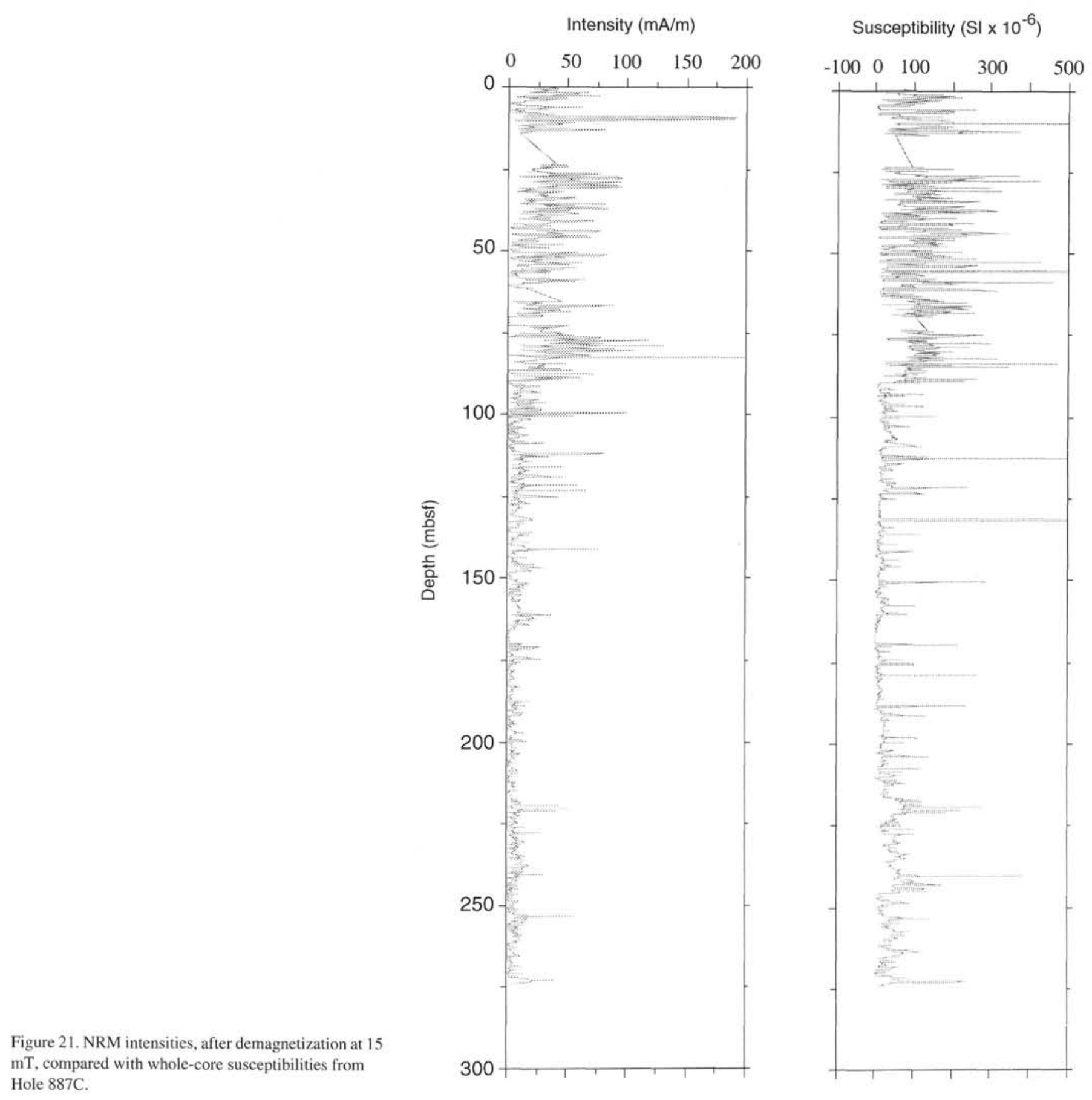


$145-887 \mathrm{~A}-7 \mathrm{H}-4,34 \mathrm{~cm}$

59.04 mbsf

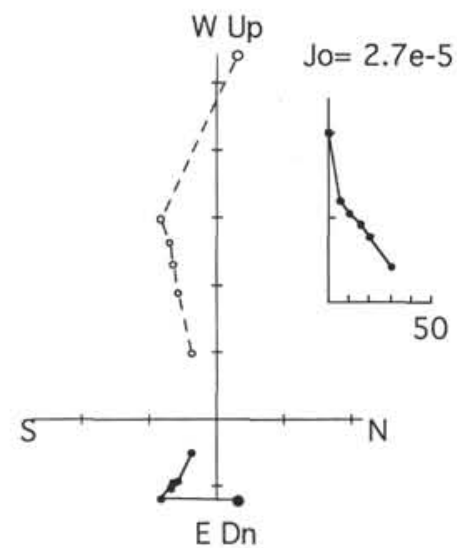

145-887A-10H-6, $125 \mathrm{~cm}$

$91.45 \mathrm{mbsf}$

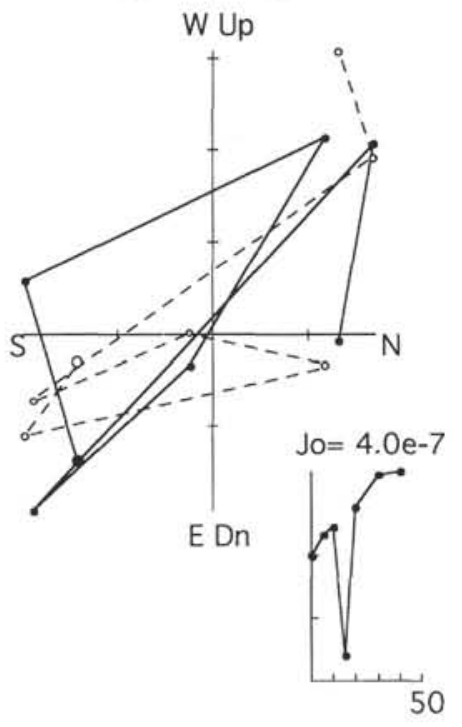

145-887A-5H-6, $125 \mathrm{~cm}$

$43.95 \mathrm{mbsf}$

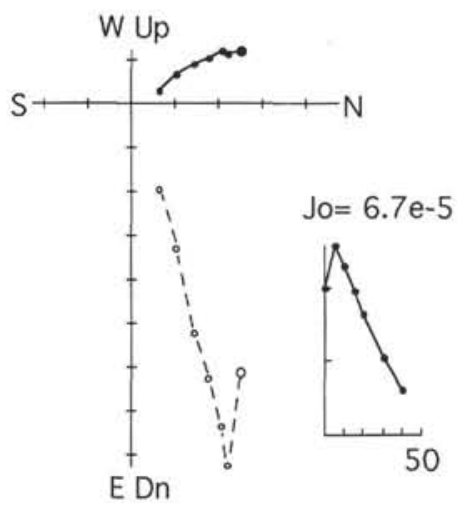

$145-887 \mathrm{~A}-11 \mathrm{H}-4,125 \mathrm{~cm}$ 97.95 mbsf

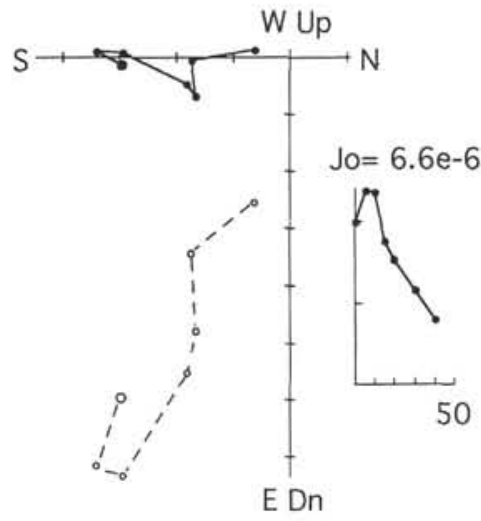

Figure 22. Representative vector component plots from discrete sample demagnetizations from Hole 887A. 
A

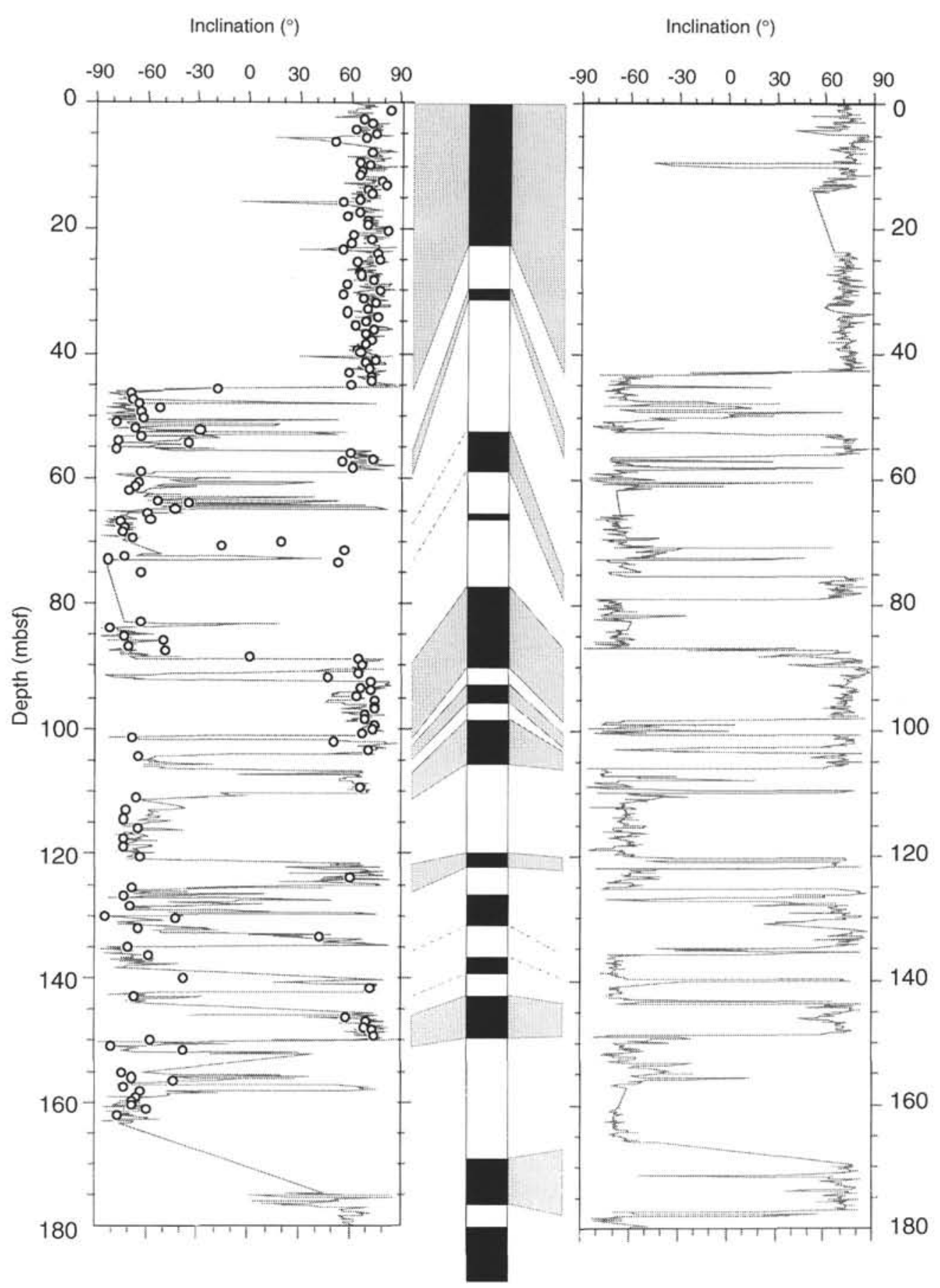

Figure 23. A. Comparison of whole-core measurements of inclination, after 15-mT demagnetization, from Holes $887 \mathrm{~A}$ and $887 \mathrm{C}$ (solid line), with results from least-squares line fits to demagnetization results from discrete samples between 15 and $40 \mathrm{mT}$ (open circles) from Hole $887 \mathrm{~A}$ for the interval $0-180 \mathrm{mbsf}$. B. Whole-core measurements of inclination, after 15-mT demagnetization, from Hole 887C, with single-sample data superimposed, for the interval 180-273 mbsf. Correlation with the geomagnetic polarity time scale of Cande and Kent (1992) is also shown. Depths to polarity boundaries are shown in Table 5 with respect to the chron nomenclature of Cande and Kent (1992). 
B

Hole $887 \mathrm{C}$

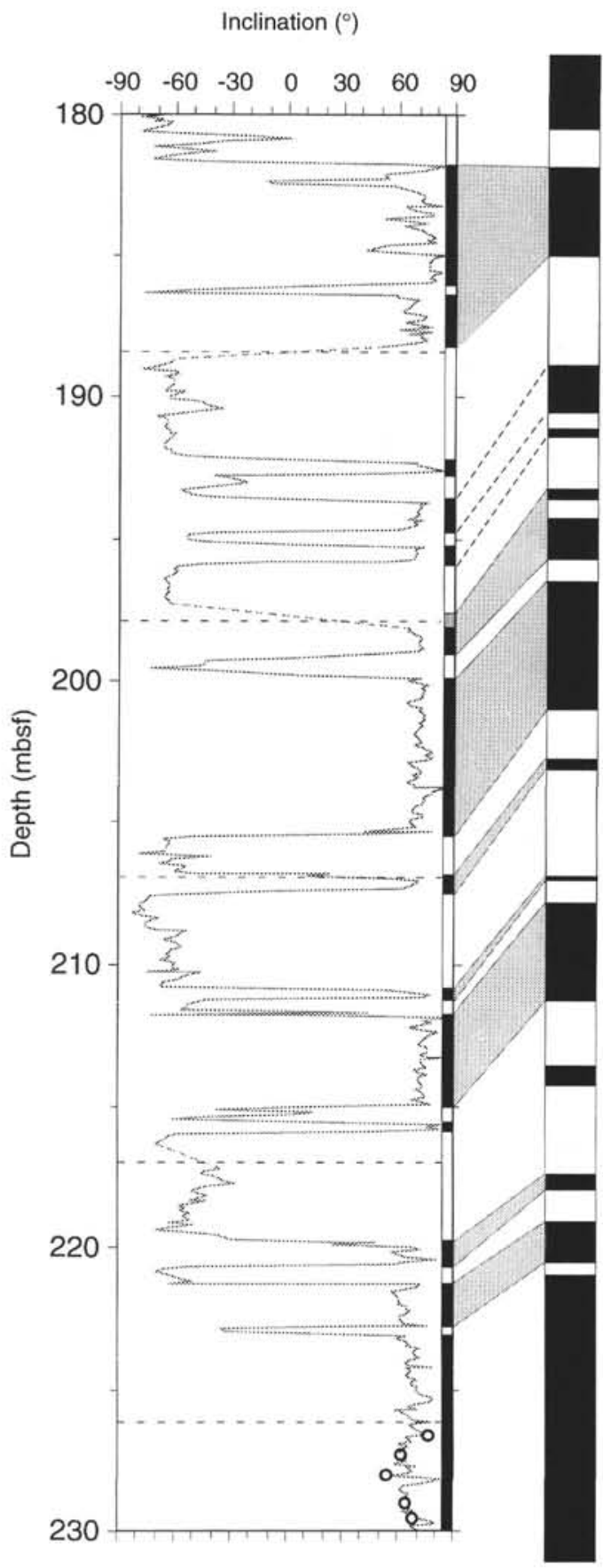

Hole $887 \mathrm{C}$

Inclination $\left({ }^{\circ}\right)$

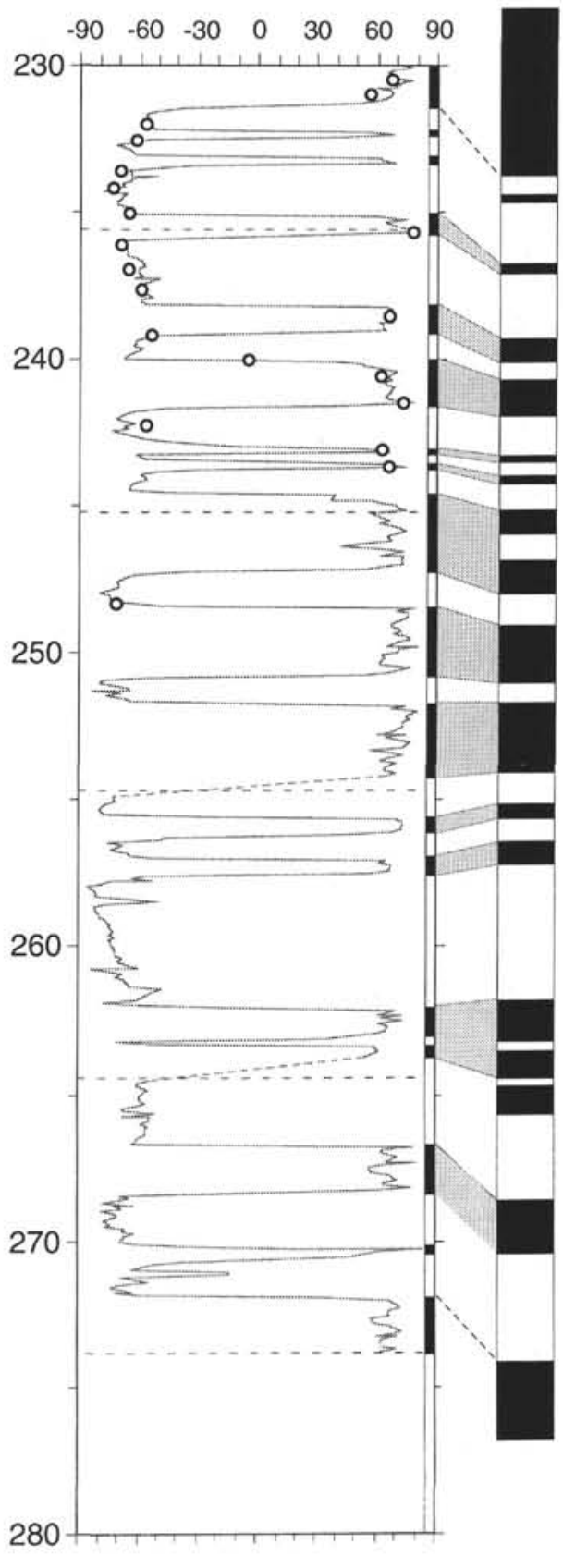

Figure 23 (continued). 
Table 5. Depths of polarity chron boundaries in Holes $887 \mathrm{~A}$ and $887 \mathrm{C}$.

\begin{tabular}{|c|c|c|c|c|c|}
\hline \multirow[b]{2}{*}{$\begin{array}{l}\text { Polarity } \\
\text { boundary }\end{array}$} & \multirow[b]{2}{*}{$\begin{array}{l}\text { Age } \\
(\mathrm{Ma})\end{array}$} & \multicolumn{2}{|c|}{ Hole $887 \mathrm{~A}$} & \multicolumn{2}{|c|}{ Hole $887 \mathrm{C}$} \\
\hline & & $\begin{array}{l}\text { Depth } \\
\text { (mbsf) }\end{array}$ & Notes & $\begin{array}{l}\text { Depth } \\
\text { (mbsf) }\end{array}$ & Notes \\
\hline $\mathrm{Cln}$ & 0.780 & 45.55 & & 42.70 & \\
\hline \multirow[t]{2}{*}{ Clr.In } & 0.984 & 55.60 & & 52.60 & \\
\hline & 1.049 & 58.95 & & 56.25 & \\
\hline \multirow[t]{2}{*}{$\mathrm{C} 2 \mathrm{n}$} & 1.757 & & f & 75.35 & \\
\hline & $\begin{array}{l}1.983 \\
2.197\end{array}$ & & f & 78.95 & \\
\hline $\mathrm{C} 2 \mathrm{r} \cdot \mathrm{In}$ & 2.229 & & & & \\
\hline \multirow[t]{2}{*}{ C2An. In } & 2.600 & 88.90 & & 87.30 & \\
\hline & 3.054 & 101.10 & & 98.30 & \\
\hline \multirow{2}{*}{$\mathrm{C} 2 \mathrm{An} \cdot 2 \mathrm{n}$} & 3.127 & 101.85 & & 100.55 & \\
\hline & 3.221 & 104.20 & & 102.70 & \\
\hline C2An.3n & 3.325 & 106.55 & & 103.40 & \\
\hline & 3.553 & 110.35 & & 105.90 & \\
\hline C $3 n .1 n$ & 4.033 & 121.10 & & 120.35 & \\
\hline & 4.134 & 125.20 & & & $\mathrm{cb}$ \\
\hline C $3 n .2 n$ & 4.265 & & & & \\
\hline C $3 n \cdot 3 n$ & $\begin{array}{l}4.432 \\
4.611\end{array}$ & 134.70 & & $\begin{array}{l}134.80 \\
139.65\end{array}$ & \\
\hline C.11.. & 4.694 & 142.20 & & & \\
\hline C $3 n .4 n$ & 4.812 & 145.80 & & 143.55 & \\
\hline & 5.046 & 149.95 & & 148.65 & \\
\hline C3An. In & 5.705 & & & $169-169.3$ & $\mathrm{cb}$ \\
\hline & 5.946 & & & 177.10 & \\
\hline C $3 \mathrm{An} \cdot 2 \mathrm{n}$ & 6.078 & & & 181.75 & \\
\hline & 6.376 & & & & \\
\hline $\mathrm{C} 3 \mathrm{Bn}$ & 6.744 & & & & \\
\hline $\mathrm{C} 3 \mathrm{Br} . \mathrm{In}$ & $\begin{array}{l}6.901 \\
6.946\end{array}$ & & & & \\
\hline & 6.981 & & & & \\
\hline $\mathrm{C} 3 \mathrm{Br} \cdot 2 \mathrm{n}$ & 7.153 & & & & \\
\hline & 7.187 & & & & \\
\hline C4n.In & 7.245 & & & & \\
\hline & $\begin{array}{l}7.376 \\
7.464\end{array}$ & & & $\begin{array}{l}199.20 \\
199.80\end{array}$ & \\
\hline$C 4 n .2 n$ & $\begin{array}{l}7.464 \\
7.892\end{array}$ & & & 205.45 & \\
\hline C4r.In & 8.047 & & & 206.80 & \\
\hline & 8.079 & & & & \\
\hline $\mathrm{C} 4 \mathrm{r} .2 \mathrm{r}-1$ & 8.463 & & & 211.25 & \\
\hline & 8.479 & & & 211.65 & \\
\hline C4An & 8.529 & & & 211.80 & \\
\hline & 8.861 & & & 215.95 & \\
\hline C4Ar.In & $\begin{array}{l}9.069 \\
9.149\end{array}$ & & & & \\
\hline C4Ar.2n & 9.428 & & & 219.75 & \\
\hline & 9.491 & & & 220.65 & \\
\hline C $5 n$. In & 9.592 & & & 221.30 & \\
\hline & 9.735 & & & 222.85 & \\
\hline C.5n.2n & 9.777 & & & 223.05 & \\
\hline C.5n. $2 \mathrm{n}-1$ & 10.065 & & & & \\
\hline C $5 n \cdot 2 n-2$ & 10.330 & & & & \\
\hline C $5 n \cdot 2 n-3$ & 10.595 & & & & \\
\hline & 10.834 & & & 231.45 & \\
\hline C5r.In & $\begin{array}{l}10.940 \\
10.989\end{array}$ & & & & \\
\hline C5r.2n & 11.378 & & & 235.15 & \\
\hline & 11.434 & & & & $\mathrm{cb}$ \\
\hline C5An.1n & 11.852 & & & 238.25 & \\
\hline & 12.000 & & & 239.50 & \\
\hline C5An.2n & 12.108 & & & 240.05 & \\
\hline & 12.333 & & & 241.65 & \\
\hline C5Ar.In & 12.618 & & & 243.05 & \\
\hline & 12.649 & & & 243.25 & \\
\hline C 5 Ar.2n & 12.718 & & & 243.45 & \\
\hline & 12.764 & & & 243.75 & \\
\hline C5AAn & 12.941 & & & & \\
\hline & 13.094 & & & & \\
\hline $\mathrm{C} 5 \mathrm{ABn}$ & 13.263 & & & 247.25 & \\
\hline $\mathrm{C} 5 \mathrm{ACn}$ & 13.476 & & & 248.45 & \\
\hline & $\begin{array}{l}13.674 \\
14.059\end{array}$ & & & 250.85 & \\
\hline C5ADn & 14.164 & & & 251.75 & \\
\hline & 14.608 & & & & $\mathrm{cb}$ \\
\hline C5Bn.In & 14.800 & & & 255.60 & \\
\hline & 14.890 & & & 256.25 & \\
\hline C5Bn.2n & 15.038 & & & 257.05 & \\
\hline & 15.162 & & & 257.55 & \\
\hline $\mathrm{C} 5 \mathrm{Cn}$ & 16.035 & & & 262.10 & \\
\hline & 16.755 & & & & $\mathrm{cb}$ \\
\hline C5Dn & 17.310 & & & 266.75 & \\
\hline & 17.650 & & & 268.40 & \\
\hline C5En & 18.317 & & & 271.95 & \\
\hline
\end{tabular}

Notes: Ages are after Cande and Kent (1992). The annotation "cb" indicates that a polarity transition occurred in a core break; "f" indicates depth of poorly recovered Olduvai interval (see text). 


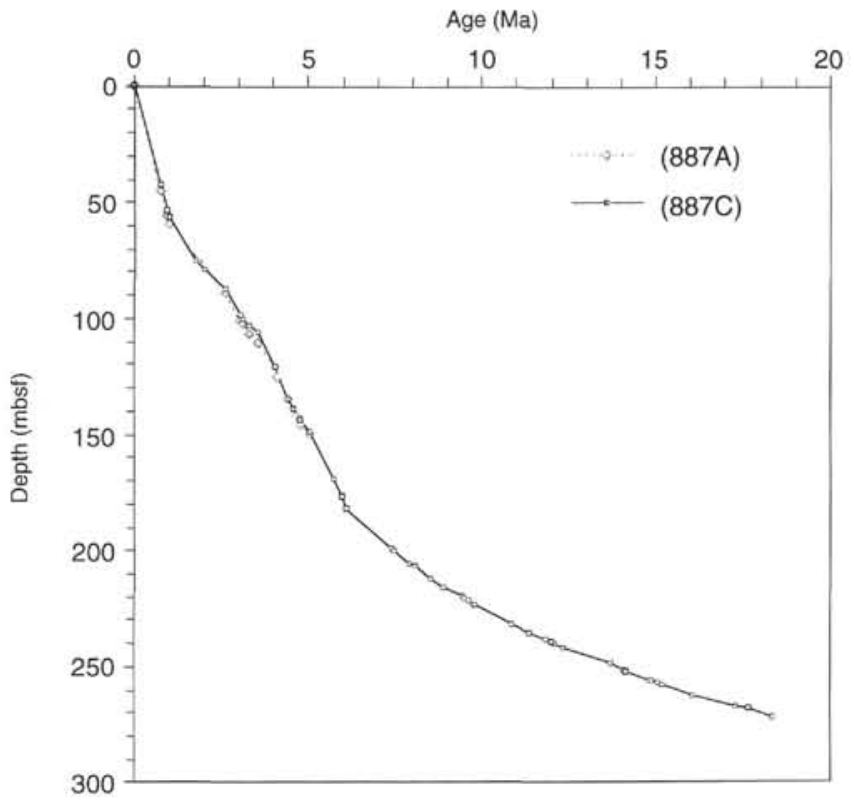

Figure 24. Plot of age vs. depth for the sedimentary section at Site 887, based on the magnetic reversal stratigraphy. 